\title{
QUANDO O RIO ERA BLACK: SOUL MUSIC NO BRASIL DOS ANOS 70'
}

\author{
When Rio was black: soul music, national culture, \\ and the politics of racial comparison in 1970s Brazil
}

\author{
Paulina L. Alberto*
}

\begin{abstract}
RESUMO
A partir de documentos encontrados nos arquivos da Polícia política do Rio de Janeiro, este artigo explora as atitudes públicas em relação ao "Black Rio": a explosão da música e da dança soul nas festas da juventude negra da classe trabalhadora nesta cidade, nos anos 70. Especificamente, o artigo usa a reação ao Black Rio por parte da polícia secreta, de oficiais militares e de outros, como a direita política, juntamente com a cobertura do fenômeno, tanto na imprensa em geral quanto na imprensa alternativa, para ilustrar as formas com que os nacionalismos de esquerda e de direita convergiram para delimitar os espaços aceitáveis para a política e a cultura negra durante essa fase do regime militar. O artigo também usa a controvérsia Black Rio para se engajar nos debates acadêmicos atuais sobre a política de estudos comparados de raça entre Brasil e Estados Unidos. O artigo demonstra que o claro entusiasmo dos dançarinos de soul pelos estilos "black" não
\end{abstract}

1 Este artigo é uma tradução de "When Rio was Black: Soul Music, National Culture, and the Politics of Racial Comparison in 1970s Brazil", originalmente publicado no Hispanic American Historical Review 89:1 (2009), pp. 3-39. Sou grata ao Eisenberg Institute for Historical Studies, da Universidade de Michigan, pela bolsa que permitiu a pesquisa para este trabalho, e pela oportunidade de apresentá-lo. Por suas atiladas contribuições em diferentes estágios, eu gostaria de agradecer a Matthew Briones, Tamar Carroll, Sueann Caulfield, Fernando Coronil, Marie Cruz, Christopher Dunn, Dario Gaggio, Juan Hernández, Jesse Hoffnung-Garskof, Bryan McCann, Farina Mir, Gina Morantz-Sanchez, Ed Murphy, Deborah Poole e Julie Skurski. Estou em dívida com os dois pareceristas anônimos do Hispanic American Historical Review pelos comentários generosos e cuidadosos. Agradeço a Mariângela de Mattos Nogueira pela excelente tradução, assim como ao Brazil Initiative do Center for Latin American Studies da University of Michigan pelo financiamento da tradução deste artigo e por torná-lo disponível no seu repositório on line "Translating the Americas": http://quod.lib.umich.edu/l/lacs/

* Ph.D. Universidade da Pennsylvania. Professora da Universidade de Michigan (EUA) 
era uma medida de reconhecimento da superioridade dos poderes políticos de ativismo racial dos EUA (como alguns estudiosos afirmam), nem uma capitulação aos padrões "imperialistas" da política racial (como outros lamentam). Pelo contrário, o entusiasmo por todas as coisas "black" entre um segmento da juventude negra do Rio foi uma tentativa de posicionar estrategicamente o contraste tradicional entre os sistemas e políticas raciais dos EUA e do Brasil para levantar a questão sobre os estreitos espaços de expressão política e cultural baseada em raça, no país.

Palavras-chave: Raça; Cultura nacional; Comparações entre Brasil e Estados Unidos.

\begin{abstract}
Using documents found in the archives of Rio de Janeiro's political police, this article explores public attitudes to "Black Rio": the explosion of soul music and soul dance parties among working-class black youth in that city in the 1970s. Specifically, the article uses responses to Black Rio among the secret police, military officials and others on the political right, together with coverage of the phenomenon in the mainstream and alternative press, to illustrate the ways in which left- and right-wing nationalisms converged to circumscribe the acceptable spaces for black politics and culture during this stage of military rule. The article also uses the Black Rio controversy to engage with ongoing scholarly debates about the politics of studying race comparatively between Brazil and the United States. The article demonstrates that soul dancers' clear enthusiasm for "black" styles was neither a measure of their recognition of the superior political powers of U.S.-style racial activism (as some scholars assert), nor a capitulation to "imperialist" standards of racial politics (as others lament). Rather, the enthusiasm for all things "black" among a segment of Rio's black youth was an attempt to strategically deploy the traditional contrast between racial systems and politics in the U.S. and Brazil to make a point about the narrowed spaces for race-based political and cultural expression at home.
\end{abstract}

Keywords: Race; National culture; US/Brazil comparisons. 


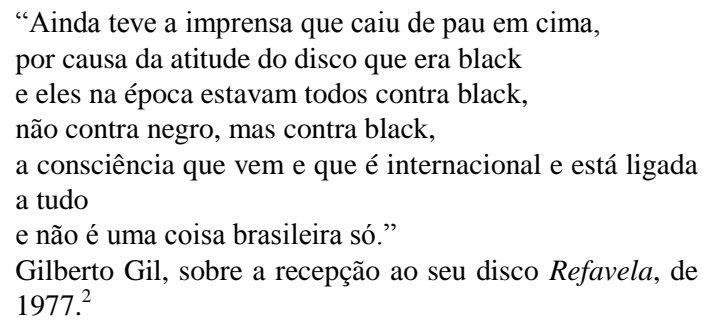

Em julho de 1976, o suplemento cultural de sábado do Jornal do Brasil dedicou quatro páginas inteiras a um assunto preocupante. O Rio de Janeiro estava virando "black", dizia a jornalista Lena Frias a seus leitores. Uma onda de bailes tocando música soul e funk dos Estados Unidos já tinha invadido os clubes recreativos dos subúrbios do Rio, os bairros da classe trabalhadora, a norte e oeste, e ameaçava chegar também aos bairros da famosa Zona Sul, os mais ricos (e mais brancos) da cidade. O artigo descrevia os bailes soul e as centenas de milhares de jovens negros que a eles afluíam como um espaço cultural à parte, de fato, um lugar para além da cidade que a maioria dos leitores pensava conhecer.

Uma cidade de cultura própria desenvolve-se dentro do Rio. Uma cidade que cresce e assume características muito específicas. Cidade que o Rio, de modo geral, desconhece ou ignora. [...] Uma cidade cujos habitantes se intitulam a si mesmos de blacks ou de browns; cujo hino é uma canção de James Brown [...]; cuja bíblia é [o filme] Wattstax, a contrapartida negra de Woodstok [sic]; cuja linguagem incorporou palavras como brother e white [...] cujo lema é I am somebody; cujo modelo é o

2 Jornegro n. 7, ano 2, 1979. Citado por DUNN, Christopher. Brutality Garden: Tropicália and the Emergence of a Brazilian Counterculture. Chapel Hill: University of North Carolina Press, 2001, p. 184. 
negro americano, cujos gestos copiam, embora sobre a cópia já se criem originalidades. ${ }^{3}$

Esta cidade paralela e seus habitantes aparentemente inspirados nas identidades racial e cultural dos negros norteamericanos era, para Frias, um "fenômeno sociológico dos mais instigantes já registrados no país". Essa cidade paralela ela chamou de "Black Rio", usando a palavra inglesa black.

A inquietante avaliação de Frias provocou uma enxurrada de artigos sobre o fenômeno soul nos principais jornais e revistas nacionais, bem como na imprensa alternativa da cidade, que representava vários grupos de esquerda e do emergente movimento negro. Acima de tudo, o artigo de Frias atraiu a atenção da Polícia secreta do estado do Rio de Janeiro. Junto com outros observadores de direita aliados da ditadura militar, então no poder, eles observavam atentamente os bailes soul e discutiam se podia tratar-se de algum tipo de "movimento" coerente, subversivo. A controvérsia soul, portanto, é uma oportunidade para se investigar de que forma os comentaristas de todo o espectro político entenderam a relação entre música, cultura nacional e política racial no Brasil dos anos setenta.

Apesar das diversas posições e do tom estridente, todos os envolvidos adotaram o nome com que Lena Frias batizou o fenômeno. Todos parecem ter acordado que a palavra inglesa black para se referir a raça, identidade, política e cultura em um contexto norte-americano considerado como racialmente mais polarizado do que o Brasil - era intraduzível em termos raciais brasileiros, porém, naquele momento, tornava-se necessária para descrever processos em curso na sociedade brasileira. Ser black era culturalmente e politicamente diferente de ser preto ou pardo, termos historicamente usados para designar a cor da pele mais escura ou mais clara de brasileiros afrodescendentes; era diferente, também, de ser negro, a palavra que muitos afro-brasileiros politicamente ativos tinham adotado desde as primeiras décadas do século para designar um grupo

3 FRIAS, Lena. "Black Rio: O orgulho (importado) de ser negro no Brasil". Jornal do Brasil, Caderno B, p. 17 de julho de 1976. 
racial orgulhosamente unificado. ${ }^{4} \mathrm{Na}$ esteira do artigo de Frias, observadores e participantes de variadas tendências lutaram para definir as implicações políticas da "blackitude" do soul. Será que as atitudes raciais estrangeiras orgulhosamente ecoadas pelo soul o tornavam perigoso, como muitos observadores de direita inicialmente acreditavam? Ou, como muitos na esquerda rebatiam, suas referências importadas o faziam culturalmente inautêntico e politicamente falido? Os riscos eram altos para todos os envolvidos, porque o soul atropelava, no cerne das imagens de identidade nacional brasileira, um contraste havia muito acalentado: os Estados Unidos racistas contra o Brasil racialmente tolerante.

As origens da idéia de que o Brasil era fundamentalmente diferente dos Estados Unidos em termos de relações raciais e definições de raça remontavam, pelo menos, ao início do século XX. Intelectuais brasileiros e estrangeiros na primeira metade deste século comumente postulavam que uma história da escravidão e da Abolição mais amena no Brasil, além da grande miscigenação racial, tinha produzido uma sociedade livre da discriminação racial. Em comparação com os Estados Unidos, que teve um sistema racial acentuadamente dicotômico, que impedia os negros de fazerem parte de uma nação branca, no Brasil, muitos alegavam, havia um sistema progressivo de identificação racial que incluía pessoas de diversas origens raciais e culturais numa nação mista ou mestiça. ${ }^{5}$ Por esta lógica, ser black, como uma identidade cultural e política radicalmente contestatória, era uma infeliz consequência do racismo e da segregação racial nos Estados Unidos, mas ficava totalmente fora de lugar numa nação tolerante e mestiça como o Brasil.

Desde as décadas de 1950 e 60, no entanto, a comparação favorável com os Estados Unidos foi submetida ao crescente ataque

4 Sobre mudança de terminologia racial entre ativistas negros ao longo do século XX, ver ANDREWS, George Reid. Blacks and Whites in São Paulo, Brazil, 1888-1988. Madison: University of Wisconsin Press, 1991; BUTLER, Kim D. Freedoms Given, Freedoms Won: AfroBrazilians in Post-Abolition São Paulo and Salvador. New Brunswick, NJ: Rutgers University Press, 1991.

5 O mais destacado entre eles era FREYRE, Gilberto. Casa grande e senzala: introdução à história da sociedade patriarcal no Brasil. 41 a ed., Rio de Janeiro: Editora Record, 2000 [1933]. Ver também TANNENBAUM, Frank. Slave and Citizen: The Negro in the Americas. Nova York: Vintage Books, 1946; DEGLER, Carl N. Neither Black nor White: Slavery and Race Relations in Brazil and the United States. Nova York: Macmillan, 1971. 
de um grupo de intelectuais e ativistas, muitos deles ligados ao movimento negro. Na década de setenta, no auge do fenômeno soul, esses críticos começaram a argumentar que o mito nacionalista de um Brasil racial e culturalmente harmonioso ofuscava uma realidade subjacente que era muito mais semelhante ao estilo do racismo dos Estados Unidos do que a maioria dos brasileiros gostaria de admitir. ${ }^{6}$ Desde então, muitos acadêmicos têm argumentado que a natureza enganadora do racismo brasileiro talvez tenha sido ainda mais perniciosa do que o racismo no estilo americano, pois neutralizou possibilidades de "consciência racial" e política racial ao estilo do Movimento por Direitos Civis nos Estados Unidos, e até hoje dificulta a realização de programas de ação afirmativa nos moldes daquele país. $^{7}$ Para muitos estudiosos engajados na crítica ao racismo brasileiro, o Black Rio, com suas referências raciais ao estilo norteamericano, foi um tônico para o mal-estar racial no Brasil. As identidades negras contestatórias que emergiram dos bailes soul representaram um breve momento de consciência racial - uma consciência longamente prejudicada por mitos da democracia racial e fracos movimentos raciais no Brasil. ${ }^{8}$

Na década de 1990, os debates sobre a comparação com os Estados Unidos deram uma guinada acentuada para os extremos. Alguns defensores da tolerância relativa do Brasil e da diferença fundamental com os Estados Unidos acusavam seus adversários de imperialismo cultural, de imposição de categorias e políticas norte-

6 Ver especialmente NASCIMENTO, Abdias do. O negro revoltado. Rio de Janeiro: Editora Nova Fronteira, 1982; NASCIMENTO, Abdias do. "O genocídio do negro brasileiro". In: NASCIMENTO, Abdias do. O Brasil na mira do pan-africanismo. Salvador: EDUFBA/CEAO, 2002.

7 HANCHARD, Michael George. Orpheus and Power: The Movimento Negro of Rio de Janeiro and São Paulo, Brazil, 1945-1988. Princeton, NJ: Princeton Univ. Press, 1994; TWINE, France Winddance. Racism in a Racial Democracy: The Maintenance of White Supremacy in Brazil. New Brunswick, NJ: Rutgers Univ. Press, 1998. Sobre ação afirmativa, ver MARTINS, Sérgio da Silva; MEDEIROS, Carlos Alberto e NASCIMENTO, Elisa Larkin. Paving Paradise: The Road from 'Racial Democracy' to Affirmative Action in Brazil. Journal of Black Studies, v. 34, n. 6, 2004, p. 787-816.

8 J TURNER, Michael. Brown into Black; e Mitchell, Michael. Blacks and the abertura democrática. Ambos In: FONTAINE, Pierre-Michel (org.), Race, Class, and Power in Brazil. Los Angeles: Center for Afro-American Studies, UCLA, 1985, pp.73-94, 95-119; HANCHARD, Orpheus and Power, pp. 114-20; MONTEIRO, Helene. O ressurgimento do Movimento Negro no Rio de Janeiro na década de 70. Dissertação de Mestrado, Universidade Federal do Rio de Janeiro, 1991. 
americanas ao Brasil, negando, assim, sua especificidade. Em resposta, alguns partidários da ideia de que os Estados Unidos e o Brasil compartilhavam padrões semelhantes de racismo retorquiam que a defesa da diferença brasileira significava uma negação, ou justificativa, das formas virulentas de discriminação no Brasil. ${ }^{9}$ Ironicamente, estes argumentos bem-intencionados em defesa dos afro-brasileiros acabaram apresentando-os, alternadamente, como joguetes de mitos nacionais de desracialização ou como vítimas de modelos imperialistas de consciência racial. ${ }^{10^{3}}$

Uma posição nova, mais sutil na comparação entre Brasil e Estados Unidos, parece emergir do ruído dessas polêmicas. Mais recentemente, alguns procuraram separar o argumento sobre se no Brasil há ou não racismo ou ativismo racial da condição de funcionamento desses fenômenos tal qual percebidos nos Estados Unidos. Ao contrário dos argumentos do início do século XX, essas tentativas de entender o Brasil em seus próprios termos não vinculam os estudiosos a um discurso laudatório da tolerância racial e do excepcionalismo. Em vez disso, eles permitem que os estudiosos explorem as maneiras como a política, identidades e discriminação racial podem existir tão vividamente no Brasil quanto nos Estados Unidos, embora com dinâmicas e manifestações distintas. ${ }^{11}$ Ao

9 Particularmente polêmico é o debate provocado pela leitura de Bourdieu e Wacquant do livro de HANCHARD, Orpheus and Power. BOURDIEU, Pierre e WACQUANT, Loïc. On the Cunning of Imperialist Reason. Theory, Culture and Society, v. 16, n. 1, 1999, pp. 41-58. Para as defesas subsequentes de Hanchard, ver HANCHARD, M. Acts of Misrecognition: Transnational Black Politics, Anti-imperialism, and the Ethnocentrisms of P. Bourdieu and L. Wacquant. Theory, Culture, and Society, v. 20, n. 4, 2003, pp. 5-29; FRENCH, John. The Missteps of Anti-Imperialist Reason: Bourdieu, Wacquant and Hanchard's Orpheus and Power. Theory, Culture and Society, v. 17, n. 1, 2000, pp.107 - 28. Para uma série de contribuições brasileiras a essa polêmica, ver a edição especial de Estudos Afro-Asiáticos (Rio de Janeiro) v. 24, n. 1 (2002).

10 Para uma visão geral desses debates, ver WADE, Peter. Images of Latin American Mestizaje and the Politics of Comparison. Bulletin of Latin American Research, v. 23, n. 3, 2004, pp. $355-66$.

11 Ver MATTOS DE CASTRO, Hebe Maria. Das cores do silêncio: os significados da liberdade no sudeste escravista, Brasil, século XIX. Rio de Janeiro: Arquivo Nacional, 1995; CAULFIELD, Sueann. In Defense of Honor: Sexual Morality, Modernity, and Nation in EarlyTwentieth-Century Brazil. Durham, NC: Duke University Press, 2000; FRY, Peter. Politics, Nationality, and the Meanings of 'Race' in Brazil. Daedalus, v. 129, n. 2, 2000, pp. 83 - 118; GOMES, Tiago de Melo. Um espelho no palco: identidades sociais e massificação da cultura no teatro de revista dos anos 1920. Campinas: UNICAMP, 2004; SHERIFF, Robin E. Dreaming Equality: Color, Race, and Racism in Urban Brazil. New Brunswick, NJ: Rutgers University Press, 
mesmo tempo, a presunção de um sistema racial brasileiro totalmente delimitado, sem sobreposição ou troca com os Estados Unidos, já não se sustenta. Contato e comparação com aquele país (e com outros fluxos internacionais de ideias e símbolos) foram sempre constitutivos das discussões internas sobre a raça no Brasil. ${ }^{12}$

A popularidade da soul music no Brasil na década de setenta oferece uma oportunidade única para explorar esta complexa interação entre referências raciais internacionais e ideologias nacionais de raça. Alguns estudos recentes sobre como o brasileiro, neste período, entendeu, apreciou e produziu a música soul traçam os caminhos, nitidamente brasileiros, que os estilos, a política e as identidades raciais do soul percorreram, mesmo que tenham conscientemente tomado de empréstimo modelos norte-americanos. ${ }^{13}$ Este artigo se desloca da música para os debates públicos sobre o Black Rio e as investigações policiais sobre este, para compreender o sentido que uma gama de brasileiros deu a essa manifestação cultural. Com excepcional eloquência, esses debates não só expõem as diversas opiniões dos brasileiros sobre a comparação com os Estados Unidos em seu próprio tempo, mas mostram participantes lidando conscientemente com essa comparação para definir raça e cultura nacional de uma forma politicamente conveniente.

Como a própria musica soul, essas leituras controvertidas do estrangeirismo do soul no Brasil de meados dos anos 70 complicam suposições, muitas vezes sustentadas por estudiosos em ambos os lados do debate sobre a comparação, acerca do poder dos modelos raciais, culturais e políticos estrangeiros de impor-se sobre as

2001; ALBERTO, Paulina L. Terms of Inclusion: Black Intellectuals in Twentieth-Century Brazil. Chapel Hill, N.C.: University of North Carolina Press, 2011.

12 Ver ANDREWS, George Reid. Brazilian Racial Democracy, 1900 - 90: An American Counterpoint, Journal of Contemporary History, v. 31, n. 3, 1996, pp. 483 - 507; FRENCH, John. Translation, Diasporic Dialogue, and the Errors of Pierre Bourdieu and Loïc Wacquant. Nepantla, v. 4, n. 2, 2003, pp. 375 - 89; e SEIGEL, Micol. Beyond Compare: Comparative Method after the Transnational Turn. Radical History Review, n. 91, 2005, pp. 62 90 .

13 MCCANN, Bryan. Black Pau: Uncovering the History of Brazilian Soul. In: HERNÁNDEZ, Deborah Pacini; FERNÁNDEZ-L'HOESTE, Héctor; e ZOLOV, Eric (orgs.). Rockin' Las Américas: The Global Politics of Rock in Latin America. Pittsburgh: Universityof Pittsburgh Press, 2004; DUNN, Brutality Garden, pp. 177 - 80; SANSONE, Lívio. Global Funk in Bahia and Rio. In: Blackness without Ethnicity. Nova York: Palgrave Macmillan, 2003, pp. 115 16. 
interpretações locais, seja positiva ou negativamente. Brasileiros em todos os lados do debate sobre o soul adotaram a palavra inglesa black. Apesar dos protestos de muitos de que era uma palavra estrangeira usada para descrever uma influência estrangeira, a palavra inglesa, na verdade, ajudou a explicar o terreno movediço da cultura e da política local. E mais uma vez, apesar das preocupações de que a adoção entusiástica pelos bailarinos do termo black para descrever a si mesmos e seus estilos pudesse destruir ou contaminar a terminologia racial local, brasileiros de todo tipo não tiveram problemas em adotar o termo nem o substituíram pela palavra brasileira "negro". Em sua utilização não traduzida deste "gesto" estrangeiro, como Frias colocou, todos aqueles envolvidos "cri[avam] originalidades".

\section{Blacks sob vigilância}

O Departamento Geral de Investigações Especiais (DGIE), braço da inteligência política, começou a investigar o fenômeno soul em abril de 1975, mais de um ano antes de o artigo de Frias ter "descoberto" o soul para um público mais amplo de leitores. O DGIE era um ramo recém-reformado das entidades comumente conhecidas como Polícia "secreta" ou "política", que existiam sob vários disfarces no Brasil desde o início do século XX. Embora seu objetivo de preservar a ordem social e política tenha se mantido constante, os ideais de ordem e os métodos da Polícia secreta para alcançá-la mudaram com o tempo. Não por acaso, o alcance e a intensidade do policiamento político atingiu o ápice nos governos repressivos, como o Estado Novo de Getúlio Vargas e a ditadura militar pós-1964. A partir do final dos anos 60 até meados dos 70, no auge da repressão política da ditadura, as forças da Polícia secreta do Rio de Janeiro (então conhecida como o Departamento de Ordem Política e Social DOPS / RJ) trabalhavam em estreita colaboração com as agências de 
inteligência federais na repressão à guerrilha urbana da esquerda organizada. $^{14}$

Quando o fenômeno soul chamou a sua atenção, a Polícia secreta do Rio passava por algumas mudanças. Em 1975, ela foi reestruturada em DGIE, com um Departamento de Polícia Política e Social, que atuaria como "inteligência policial", coletando informações sobre pessoas e instituições consideradas perigosas para a segurança nacional. ${ }^{15}$ Esta reorganização institucional coincidiu com uma mudança na atmosfera política da nação, que iria mudar a natureza tanto do ativismo político quanto do policiamento político. Na segunda metade da década de setenta, tendo já desarmado a esquerda institucional com sucesso e em resposta à crescente oposição de setores políticos moderados, a ditadura entrou numa fase de distensão, em que a oposição ao regime foi menos rigorosamente definida, investigada e punida. A atenuação da repressão do Estado permitiu o surgimento de novos movimentos sociais e políticos. ${ }^{16}$ Por um lado, isso tornou a tarefa da Polícia política mais fácil; esses movimentos lutavam por meios pacíficos, ao contrário dos guerrilheiros urbanos de anos anteriores. No entanto, eles também traziam novos problemas para a DGIE. Como no resto da América Latina, estes novos movimentos sociais desafiaram os partidos políticos estabelecidos e organizados em torno de ideologias tradicionais de esquerda e direita e reconfiguraram mais amplamente as noções da "política".

Esta difusão da "política", que se tornou ao mesmo tempo onipresente e difícil de definir, desafiava as categorias de subversão política ("terrorismo", "comunismo", "Cuba") com as quais a Polícia estava acostumada a lidar. A Polícia enfrentou justamente este desafio

14 Sobre a Polícia política do Rio de Janeiro, ver DAVIS, Darien J.The Arquivos das Polícias Politicais [sic] of the State of Rio de Janeiro. Latin American Research Review, v. 31, n. 1, 1996, pp. 99 - 104; e Arquivo Público do Estado do Rio de Janeiro, Os arquivos das polícias políticas: reflexos de nossa história contemporânea. Rio de Janeiro: Fundação de Amparo à Pesquisa do Estado do Rio de Janeiro, 1996.

15 Isto se seguiu a fusão dos estados do Rio de Janeiro e da Guanabara. DAVIS, The Arquivos, p. 101.

16 ALVAREZ, Sonia E. Engendering Democracy in Brazil: Women's Movements in Politics. Princeton, NJ: Princeton University Press, 1990; ARAUJO, Maria Paula Nascimento. A utopia fragmentada: as novas esquerdas no Brasil e no mundo na década de 1970. Rio de Janeiro: FGV Editora, 2000. 
com os bailes soul, seu primeiro encontro importante com as associações e movimentos negros que começavam a florescer na segunda metade da década de setenta. Organizações negras, como a Frente Negra dos anos 30 ou o Teatro Experimental do Negro das décadas de quarenta e cinquenta, já haviam merecido a atenção da Polícia secreta do Rio de Janeiro, mas apenas de modo pontual; não havia uma categoria formal para o ativismo negro nas listas da Polícia. Seus relatórios iniciais sobre o fenômeno soul, antes da publicação do artigo de Lena Frias, que foi um divisor de águas, revelam a Polícia reconhecendo o soul como uma potencial ameaça a ordem e segurança públicas, mas lutando para categorizar a natureza dessa ameaça. Em 19 de abril de 1975, agentes do DGIE infiltraramse num grande baile soul, comandado por dois conjuntos musicais chamados Black Power e Soul Grand Prix, na quadra da Escola de Samba Portela. O relatório daí resultante, cujo "assunto" e título "Black Power" confundia o nome do grupo com sugestões de radicalismo racial, revela a principal preocupação da Polícia com o tratamento preferencial que os organizadores davam às "pessoas de cor":

Esse 'show' teve a presença de cerca de seis mil pessoas de cor e os ingressos foram vendidos nas seguintes condições: pessoa branca, Cr. 15,00; pessoa de cor, $\mathrm{Cr}$. 10,00. Durante o baile, ao som da moderna música americana, os bailarinos gritavam os nomes de vultos negros famosos, com[o] Luther King [sic] e Jimmy Hendrix. Observou-se, também, que os poucos brancos ali presentes foram hostilizados mediante a aplicação de 'guerra fria' e que os bailarinos fizeram uso de grande quantidade de maconha.

O grupo Black Power, alegava o relatório, havia sido proibido de tocar em outro clube social, o Grêmio Recreativo Rocha Miranda, "porque não queriam permitir o ingresso de pessoas de cor 
branca" ${ }^{17}$ Discriminação racial desse tipo era tecnicamente um crime no Brasil, pois violava a Lei Afonso Arinos (aprovada em 1951, em resposta a casos de racismo contra negros brasileiros e estrangeiros). No entanto, a Polícia no Brasil jamais havia processado de forma consistente as muitas violações desta lei quando os afro-brasileiros eram as vítimas da discriminação. ${ }^{18}$

Em relatórios subsequentes, os funcionários que discutiram a discriminação contra os brancos nesses bailes soul mostravam desacordo sobre se esta era equivalente ou pior do que a discriminação contra os negros, muito mais prevalente na sociedade brasileira. Passado um ano de investigação, por exemplo, um investigador de Polícia apresentou um relatório em que descreve como "radicalismo" os processos pelos quais os produtores do baile soul "procuram dificultar a entrada de [...] brancos", mas explicou que esse radicalismo apenas ecoava as práticas de clubes de rock da Zona Sul, que rotineiramente faziam a mesma coisa com "negros". 19 Em suas notas marginais a este relatório, as autoridades debatiam a questão da discriminação racial de modos que revelam uma visão desequilibrada do que significava defender a democracia racial brasileira. O delegado de Polícia Nahli Jorge Hauat pressionou o investigador a informar "com detalhe até que ponto existem as dificuldades impostas pelos patrocinadores no que diz respeito ao radicalismo". ${ }^{20}$ Ele não recebeu as respostas em relação aos bailes soul, o que sugere que a Polícia ainda não tivesse nenhuma direção segura sobre a questão, mais de um ano depois de suas investigações iniciais. Mas, outro oficial de alto escalão, Deuteronômio Rocha dos Santos, aparentemente sentiu-se compelido a responder às passagens do relatório que acusavam clubes brancos de "radicalismo" (passagens que alguém, talvez ele, havia marcado com um redondo

17 Arquivo Público do Estado do Rio de Janeiro, Fundo Polícias Políticas no Rio de Janeiro, sector DGIE, pasta 241 (doravante DGIE seguido do número da pasta), pp. 245 - 44, 29 de agosto de 1975. A ordem decrescente de paginação em todos os documentos do DGIE citados reflete a dos originais.

18 George Reid Andrews encontrou um único caso bem-sucedido de condenação por racismo contra negros pela Lei Afonso Arinos, no período entre 1951 e 1988. ANDREWS, Blacks and Whites in São Paulo, Brazil, p. 318 n. 11.

19 DGIE 252, pp. $8-7,23$ de agosto de 1976.

20 DGIE 252, p. 9v, 24 de agosto de 1976. 
"não" nas margens): "O radicalismo a que se refere o sindicante consiste na prática, utilizada em alguns recintos de Associação e Clubes tanto da Zona Norte, como na Sul, em não permitir o ingresso de pessoas que não sejam associados ou não estejam convenientemente trajadas. Desse modo há uma série de atritos entre porteiros de clubes e visitantes. Esse fato ocorre em Clubes considerados de elite, como é o caso do Iate Clube do RJ, Hípica Brasileira, Clube Militar, etc." ${ }^{21}$ Sua rejeição a quaisquer distinções feitas nas admissões a clubes de brancos de "elite" como uma questão de classe ou de "adesão", em vez de raça, tinha um tom comum às defesas conservadoras da democracia racial brasileira.

Mesmo sem muita evidência concreta de discriminação contra brancos, as investigações iniciais da Polícia evidenciavam uma percepção de que novas formas de identificação racial, ofensivas e não brasileiras, estavam em curso entre os dançarinos de soul. $\mathrm{O}$ primeiro relatório sobre o baile na Portela passou a descrever outro baile, no final de abril 1975, em que "os 'Black' promoveram a concentração de quatro mil pessoas de cor nas dependências do "Cascadura Tenis Clube'". A Polícia interpretou como suspeito o que via como tentativas explícitas dos "black" de concentrar "pessoas de cor" em torno de uma forma particular de estilo e lazer. Sua distinção entre foliões em geral ("pessoas de cor") e aqueles que viam como instigadores de estilos e identidades racialmente organizados ("blacks") sugere uma percepção da diferença fundamental entre as identidades raciais locais (difusas) e as importadas (definidas, nítidas). O relatório termina levantando uma suspeita que frequentemente acompanhava as investigações sobre os bailes soul neste período: a possibilidade de um "negro americano" estar envolvido no Grupo Black (um grupo de promoção de bailes soul), ou que o Grupo Black tivesse financiamento de fora do país. ${ }^{22}$ Incomodada com a "blackitude" do soul, mas relutante em considerar que brasileiros "de cor" pudessem ter desenvolvido por conta própria

21 Ibid

22 DGIE 241, pp. 245 - 44, 29 de agosto de 1975. Ver também DGIE 252, p. 10, 22 de julho de 1976, e DGIE 250, pp. 728 - 27, 23 de agosto de 1976. 
essas ideias contestatórias de raça, a Polícia procurava (em vão) por um agente estrangeiro infiltrado que fosse a sua fonte.

$\mathrm{Na}$ verdade, a soul music tinha sido uma parte importante da música brasileira e do cenário social do Rio pelo menos desde o início da década. O historiador Bryan McCann traça o surgimento de um estilo soul brasileiro a partir da experiência transnacional de músicos como Tim Maia, Tony Tornado, Gerson Rei Combo e da banda Abolição desde o início da década de setenta. Os bailes soul nos subúrbios do Rio de Janeiro, ele argumenta, surgiam mais ou menos independentemente dessas tendências musicais, como parte das atividades de lazer de clubes de futebol de bairro (frequentados por pessoas da classe trabalhadora, muitas delas afrodescendentes) ou de clubes das classes médias negras, como o Clube Renascença. Embora as origens exatas dos bailes soul sejam difíceis de determinar, McCann escreve que por volta de 1972 DJ's promoviam nestes clubes recreativos bailes em que tocavam soul music americana, e, em 1974 os promotores dos bailes começaram a adotar uma ampla gama de símbolos que denotavam e afirmavam os estilos e modas da negritude dos Estados Unidos. ${ }^{23}$

Em meados da década de setenta, quando a Polícia secreta começou suas investigações, os bailes haviam se tornado negócios bem organizados em grande escala. O grupo Black Power tinha alcançado fama entre as centenas de grupos de soul que havia no Rio e, como observa McCann, cada vez mais assumia a direção e o controle dos clubes sociais como organizadores e agentes dos bailes. ${ }^{24}$ Seus membros distribuíam folhetos em bailes ou colavam-nos nas paredes por toda parte nos subúrbios do Rio de Janeiro e da Zona Norte, anunciando festas quase todas as noites. Os folhetos apresentavam as bandas de destaque e procuravam seduzir os dançarinos com promessas de prêmios para as melhores roupas, sorteios de LP's lançados recentemente e com a possibilidade de aparecer em estações de rádio e TV's locais. ${ }^{25}$ Os espaços variavam de pequenos clubes sociais de bairro a espaçosas salas de ensaio das

23 MCCANN, Black Pau, pp. $69-70,77-82$.

24 Ibid., p. 82.

25 Alguns desses folhetos aparecem na pasta DGIE 252, pp. $6-2$. 
escolas de samba do Rio de Janeiro. No seu auge, em meados da década de setenta, os bailes soul atraiam um público de até 15 mil pessoas de cada vez, um total estimado de um milhão e meio de dançarinos soul. ${ }^{26}$ Gravadoras brasileiras e multinacionais correram para entrar neste lucrativo mercado, lançando álbuns de compilação de canções estrangeiras, bem como gravações de artistas de soul de casa. $^{27}$

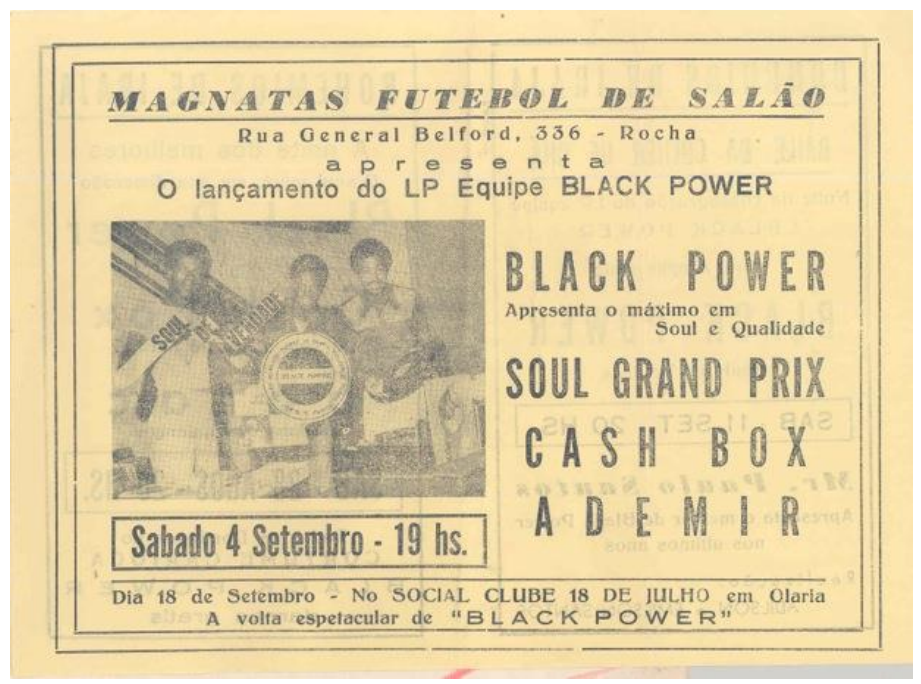

Figura 1 Folheto de 1976 anunciando um baile soul em um subúrbio do Rio com o grupo Black Power, entre outros. Da coleção do Arquivo Público do Estado do Rio de Janeiro, Fundo Polícias Políticas no Rio de Janeiro, DGIE sector, pasta 252, p. 03. Reproduzido com permissão.

26 Hermano Vianna estima que havia até 15.000 dançarinos por evento, realizados diariamente, de segunda a domingo. VIANNA, Hermano. O mundo funk carioca, Rio de Janeiro: Zahar, 1988, p.21, 26. Frias estimou cerca de 300 conjuntos no Rio, com bailes quase todas as noites variando de 5.000 a 15.000 pessoas. O suplemento cultural Um e Meio, do Jornal do Comércio, do Rio, estimou o número total de dançarinos em "milhões" (Black Rio, Um e Meio, p. 20-21 novembro de 1977), enquanto um DJ no artigo de Frias estimava entre um e dois milhões.

27 FRIAS, Black Rio. Para saber mais sobre a indústria fonográfica de soul, ver BAHIANA, Ana Maria. Enlatando Black Rio. In: Nada será como antes: MPB nos anos 70. Rio: Civilização Brasileira, 1980; e MCCANN, Black Pau, pp. 83 - 84. 
A crescente popularidade do soul e a ascensão da visibilidade do Black Power, como um importante grupo de música, alimentavam os temores da Polícia secreta de que os bailes pudessem ser o início de um movimento racial de massa com apoio organizado. Em agosto de 1975, a DGIE levou para interrogatório os membros do Black Power - Paulo Santos Filho, Emilson Moreira dos Santos e Adilson Francisco dos Santos. Confrontados com as acusações e as suspeitas da Polícia, os jovens "negaram a prática de qualquer modalidade de discriminação racial bem como a proibição de atuarem no 'Grêmio Recreativo Rocha Miranda" e "afirmaram desconhecer a presença de um negro americano no Grupo Black". ${ }^{28}$ Que a Polícia tenha chamado os suspeitos de "jovens de cor", enquanto se referia ao potencial aliado dos Estados Unidos como "negro", mais uma vez sugere sua percepção de que deveria existir uma diferença entre os sistemas raciais do Brasil e dos Estados Unidos. O termo "negro", apesar de não chamar a atenção para si tão dramaticamente como "black", ainda denotava uma identidade coletiva de estilo americano mais forte do que "de cor".

Embora o interrogatório da Polícia aos membros do Black Power tenha se centrado nas preocupações relativamente novas com os movimentos raciais e a "discriminação racial", seus arquivos ainda guardavam, sobretudo, material relacionado com a repressão mais longamente travada à esquerda organizada. Quando a Polícia procurou os nomes dos suspeitos em seus arquivos, descobriu, por exemplo, que Paulo dos Santos (o proprietário do Black Power) já tinha assinado uma petição a favor da legalização do Partido Comunista, e que João Batista do Nascimento (membro do Grupo Black) havia sido acusado de fazer "propaganda subversiva" durante o governo de centro-esquerda de João Goulart na década de $1960 .^{29}$ Em uma entrevista ao historiador Hermano Vianna, vários anos mais tarde, outro DJ, chamado Nirto, explicou que ele e seu primo Dom Filó (ambos do Soul Grand Prix) acabaram na prisão, "pois a polícia política achava que por trás das equipes de som existiam grupos 
clandestinos de esquerda". ${ }^{30}$ No contexto de mudanças na definição de política, a Polícia tentou dar sentido ao soul adaptando suas práticas estabelecidas e sua base de conhecimento (vigilância da esquerda, ligações com agitadores estrangeiros) às políticas de identidade menos familiares do soul.

As medidas de "subversão" relativamente estreitas da Polícia tornaram-na incapaz, muitas vezes, de articular totalmente alguns dos aspectos culturalmente contestatórios do soul. Isto parece estar presente em um relatório sobre um grande baile, a Terceira Caravana Soul, realizado em junho de 1976 no clube Império Serrano. Os organizadores do baile, de acordo com os registros policiais, exibiram o filme Wattstax pela primeira vez no Brasil. ${ }^{31}$ Wattstax é um documentário sobre o festival de música soul e funk promovido pela gravadora Stax e realizado, em 1972, no icônico bairro afroamericano Watts (em Los Angeles) para comemorar as rebeliões raciais que ali ocorreram em 1965. O filme intercala cenas da vida cotidiana no bairro (como entrevistas com os moradores sobre questões raciais e políticas) com comentários do comediante Richard Pryor e clips do festival de música em que Jesse Jackson foi MC. No Brasil da década de setenta, o governo militar proibiu estritamente filmes (especialmente os norte-americanos) que tratassem de assuntos explicitamente raciais. Os censores deveriam estar em alerta a quaisquer filmes que, entre outras coisas, retratassem problemas raciais no Brasil ou se referissem ao Black Power nos Estados Unidos. $^{32}$ No entanto, a Polícia secreta viu pouco a se temer na exibição de Wattstax em bailes soul. Seu relatório sobre a Terceira Caravana Soul observou que "A exibição do filme Watts Tax [sic] foi totalmente truncada, aparecendo somente algumas cenas, sem qualquer sistema de áudio funcionando, em apresentação meramente visual e desprovida de qualquer demagogia". 33

30 VIANNA. $O$ mundo funk carioca, pp. $27-28$.

31 DGIE 250, p. 731, 2 de julho de 1976. É improvável que esta tenha sido realmente a primeira exibição de Wattstax. O artigo de Lena Frias, publicado apenas um mês depois da festa Caravana do Soul, afirmava que o filme já era um clássico entre os dançarinos de soul.

32 KENNEDY, James H. Political Liberalization, Black Consciousness, and Recent Afro-Brazilian Literature. Phylon, v. 47, n. 3, 1986, p. 203.

33 DGIE 250, pp. 731 -29, 2 de julho de 1976. 
O fato de a Polícia secreta negar o potencial político de Wattstax, em razão da ausência de som, sugere habilidades limitadas, até aquele ponto de suas investigações, para perceber o poder que as imagens visuais tinham de inspirar e comunicar novos tipos de identidade racial e política. Com suas cenas vibrantes de quase cem mil negros americanos ostentando cabelos afros, dashikis e distintos estilos de soul e funk, e a superlotar o LA Coliseum num evento para uma comunidade majoritariamente negra durante o qual Jesse Jackson levantou o público (de punhos erguidos) com uma interpretação empolgante de seu poema "I am somebody" (suas palavras cintilando nos painéis do estádio) e com o Hino Negro Nacional, Wattstax comunica uma afirmação de negritude e orgulho racial para os quais nenhuma trilha sonora ou discurso político teriam sido necessários. Por todo o Rio, os organizadores de bailes soul projetavam slides sem som de cenas de filmes negros norte-americanos, como Shaft (1971), Wattstax (1972) e Claudine (1974) como uma forma de ressaltar o tema "black is beautiful". Nas famosas festas "Noites do Shaft" do Clube Renascença, por exemplo, os organizadores intercalavam essas com imagens dos dançarinos de semanas anteriores, a fim de criar uma orgulhosa identificação dos dançarinos com negros famosos e bonitos. $^{34}$ Ter a trilha sonora disponível, no entanto, parecia intensificar o poder do filme. Apenas um mês após a Caravana Soul, Lena Frias descreveu uma exibição de Wattstax no Museu de Arte Moderna do Rio, onde, ela alegou, assim como em exibições similares na Zona Norte do Rio, pessoas da audiência acompanharam Jesse Jackson, de punhos erguidos, enquanto entoavam em uníssono "I am somebody". 35 Frias acrescentou que frases do filme "são decoradas, repetidas, estampadas nas roupas, cantadas, cantaroladas, dançadas, assoviadas". 36

34 Para mais informações sobre os bailes soul "Noites do Shaft" do Renascença na década de setenta, ver GIACOMINI, Sonia Maria. A alma da festa: família, etnicidade e projetos num clube social da zona Norte do Rio de Janeiro, o Renascença Clube. Belo Horizonte: UFMG / Rio de Janeiro: IUPERJ, 2006, pp. 195 - 96.

35 O Museu de Arte Moderna era um local de inovação cultural e oposição ao regime, também acompanhado de perto pela Polícia por suas atividades "subversivas". DGIE 252, pp. 125 22,30 .

36 FRIAS, Black Rio. 
No entanto, a Polícia, durante sua primeira visão de Wattstax na Terceira Caravana Soul, estava menos preocupada com o potencial político da moda do que com o fato de que "um clima de tranquilidade" parecia caracterizar esta e outras festas, em que "não se observou nenhum tipo de discriminação ou animosidade entre pessoas de qualquer raça, todas, indistintamente, gozando dos mesmos privilégios". Mesmo a presença desproporcional de "pessoas de cor" nos bailes era "admissível", segundo eles, "porquanto o tipo de música exibido (soul) é originário dos guetos norte-americanos", e, portanto, logicamente apelava principalmente para as "pessoas negras". 37 A Polícia, em outras palavras, estava em busca de provas concretas de discriminação racial ou movimentos raciais organizados, não de ameaças simbólicas. Durante sua infiltração na Caravana Soul, a Polícia secreta levou Tony Tornado ao pé da letra quando ele declarou para o público que (conforme a Polícia o parafraseou) o movimento "não tinha qualquer cunho político ou social, querendo apenas integrá-los ao meio musical". Eles encontraram confirmação adicional quando Tornado, "entrevistado a seguir por um dos observadores, que se identificou como estudante recém-chegado do Recife exclusivamente para vê-lo (o que o deixou muito satisfeito), nada comentou e nada aduziu ao que já dissera" sobre política no movimento. ${ }^{38}$

Não está claro se o "observador" em questão era um folião ou um dos próprios agentes posando de ávido dançarino soul. Esta era uma técnica da Polícia secreta no Rio e em outros lugares utilizada para infiltrar-se nas reuniões de uma gama de organizações sociais e políticas que eles considerassem suspeitas ou subversivas. ${ }^{39} \mathrm{~A}$ probabilidade de que agentes tenham posado de dançarinos levanta a questão do perfil racial e de classe e dos investigadores. Só faria sentido que os agentes selecionados para se infiltrar nos bailes tivessem a pele relativamente escura, dada a evidente presença de

37 DGIE 250, pp. 731 - 29, 2 de julho de 1976.

38 Ibid.

39 Ver, por exemplo, NEGRO, Antonio Luigi e FONTES, Paulo. Trabalhadores em São Paulo: ainda um caso de polícia. In: AQUINO, Maria Aparecida de; LEME DE MATTOS, Marco Aurélio Vannucchi; e SWENSSON, Walter Cruz (orgs.). No coração das trevas: o DEOPS / SP visto por dentro. São Paulo: Arquivo do Estado / Imprensa Oficial, 2001, p. 166. 
poucos brancos. Também é provável que os oficiais de nível mais baixo enviados para investigar eventos como os bailes fossem de classe semelhante a dos dançarinos de soul - moradores não de favelas, mas de bairros de classe operária ou média baixa. Talvez a percepção dos agentes da relativa inocência de estilos e modas musicais - desde que permanecessem dentro dos limites da lei seja resultado de seus contatos próximos com os dançarinos de soul que conheciam de seus bairros ou famílias. Seja por uma cegueira para as políticas do estilo, ou uma percepção de sua relativa inocuidade, parece que até o início de julho de 1976, na véspera da publicação do artigo de Frias, os investigadores estavam dispostos a moderar a vigilância sobre o soul. Ele simplesmente não era uma ameaça para o que a Polícia, então, pensava ser a segurança nacional.

\section{Black Rio: Lena Frias toma o pulso da nação}

O artigo de Lena Frias, de 17 de julho de 1976, alertou um conjunto de pensadores brasileiros, incluindo uns poucos membros da Polícia secreta, para a possibilidade de que a cultura soul do Rio tivesse implicações políticas mais profundas. Especificamente, o artigo de Frias decifrava de que modo o codificado imaginário racial dos estilos soul ameaçava imagens caras à identidade nacional brasileira. Lançando um olhar sensacionalista, Frias abriu seu artigo no registro do medo: o soul era de caráter separatista e estava ganhando popularidade. Ela escreveu com um olhar quase antropológico, como se estivesse descrevendo uma cultura verdadeiramente diferente (ou até mesmo um culto) que tinha se infiltrado perigosamente num Rio que era como convinha ser. Os "adeptos do soul", explicou ela, são "os habitantes da cidade negra no Rio, uma cidade quase secreta, na medida em que é ignorada, mas cujos habitantes se conhecem muito bem. Conhecem-se e se reconhecem através de sinais próprios, modos próprios de cumprimentar, maneiras de se vestir e de se apresentar". Para ilustrar o artigo, Frias incluiu várias fotografias de grandes dimensões (de 
Almir Veiga) dos "tipos" que compunham o Black Rio - closes de jovens, homens e mulheres vestindo boinas, óculos de Lennon, calças tubinho, sapatos de plataforma e afros. (Num claro exemplo de simbolismo cultural e político misturado, este penteado era, às vezes, chamado de "cabelo black power"). Outra série de fotos capturava jovens executando o que Frias, tratando como um fenômeno exótico, chamou, numa legenda, de "etapas do complicado ritual de cumprimento black". ${ }^{40}$

Black Rio, segundo Frias, não era apenas negro nas suas referências e práticas culturais separatistas norte-americanas; era, literalmente, um espaço urbano negro ou de maioria não branca. Para Frias, como para muitos outros que escreveram sobre o movimento soul depois dela, a categoria de espaço físico captava melhor a natureza e as preocupantes implicações de separação racial do soul. O fenômeno soul enraizou-se nos bairros da classe trabalhadora na periferia do Rio de Janeiro (Zona Norte e Grande Rio), caracterizados por um percentual de afro-brasileiros maior do que os mais brancos, de classe média e alta da Zona Sul. Na visão de Frias e de outros, o fato de que em sua maioria eram os negros que frequentavam esses bailes reforçava as imagens desses bairros como principalmente não brancos (apesar da diversidade étnica real dos seus habitantes), literalmente, um black Rio. A comparação com os Estados Unidos serviu para ressaltar a estranheza para o Brasil de tal segregação racial. Os bairros da Zona Norte do Rio estavam desenvolvendo "um ar de Harlem", nos contou Frias, descrevendo uma fotografia de paredes cobertas de propaganda em grafites de bandas soul com nomes em inglês. ${ }^{41}$

Seria difícil argumentar que os bailes soul tivessem criado os bem conhecidos padrões de segregação espacial do Rio, que datavam de pelo menos o início do século XX. O que os observadores como Frias implicitamente lamentavam, quando descreviam o separatismo espacial do Black Rio, era a explícita reconfiguração da cultura popular do Rio - imaginada, por muito tempo, como unificada e compartilhada entre as camadas sociais — coincidir com a segregação

40 FRIAS, Black Rio.

41 Ibid. 
espacial prevalente da cidade. Frias acrescentou gosto musical a esta associação esquemática entre geografia e identidade racial para argumentar que era o soul que estava dividindo sua cidade: "Soul hoje, no Grande Rio, é um sinônimo de negro, como rock é sinônimo de branco". U2 Uma cidade e uma paisagem musical segregadas colocavam, assim, um perigo direto à identidade mestiça do Rio (e, por extensão, do Brasil). Como o capitão da Polícia, que viu a discriminação por "pessoas de cor" como uma ameaça maior do que a discriminação contra elas, Frias preocupou-se menos com a imitação da cultura estrangeira pelos roqueiros brancos do que com a aparente alienação dos black ao rejeitar símbolos de uma cultura nacional afrobrasileira. Black Rio, ela pronunciava, era "essa população que não tem samba e feijoada entre as suas manifestações cotidianas e folclóricas. Embora possa até gostar de samba e de feijoada como qualquer estrangeiro gosta. Uma população cujos olhos e cujos interesses voltam-se para modelos nada brasileiros". ${ }^{3}$

Os pressupostos fundamentais da identidade nacional, em que se baseava a desconfiança de Lena Frias sobre o soul, eram amplamente compartilhados entre os brasileiros de seu tempo. Desde a década de 1930, o Estado e os intelectuais brasileiros haviam promovido uma identidade nacional baseada em ideias de miscigenação cultural e racial. A versão mais conhecida dessas ideias é do sociólogo brasileiro, Gilberto Freyre, que argumentava que uma longa história de íntimas relações familiares, que remonta ao período colonial, tinha suavizado a escravidão brasileira, estabelecendo as bases de uma sociedade mais mestiça, mais afeita às influências culturais africanas e mais tolerante em termos raciais do que os Estados Unidos - uma postura que ele mais tarde chamaria de "democracia racial". ${ }^{44}$ Ao longo dos anos 30 e 40, Getúlio Vargas inspirou-se nestas ideias de identidade cultural mista e harmonia

42 Ibid.

43 Ibid.

44 Embora Freyre, notoriamente, tivesse exposto suas idéias relativas a mistura e harmonia raciais do Brasil em seu clássico de 1933, Casa grande e senzala, ele não cunhou o termo "democracia racial" até suas publicações do pós- Guerra, a exemplo de FREYRE, Gilberto. The Masters and the Slaves: A Study in Brazilian Civilization. Trad. Samuel Putnam, Nova York: Knopf, 1946. Ver GUIMARÃES, Antônio Sérgio Alfredo. Classes, Raças e Democracia. São Paulo: Editora 34; Fundação de Apoio à Universidade de São Paulo, 2002, cap. 5. 
racial para seu projeto de unificação nacional. Sob o governo de Vargas, determinados produtos culturais de origem africana - como o samba ou o prato principal da cozinha de escravos, a feijoada tornaram-se ícones de uma identidade brasileira supostamente mista e harmoniosa. ${ }^{45}$ Assim como o samba, em particular, alcançava o status de símbolo nacional, a cidade do Rio (cidade natal do samba) tornouse cada vez mais identificada com os ideais de mestiçagem e harmonia racial. Nos discursos oficiais, o samba carioca tornou-se a forma musical que os brasileiros de todas as classes e cores compartilhavam; a prova de que, apesar das desigualdades sociais encarnadas nas paisagens do Rio de Janeiro, a cultura do Brasil era essencialmente democrática. ${ }^{46}$ Nas décadas 1930 e 40, então, o contraste entre o Brasil mestiço e racialmente democrático e os Estados Unidos racialmente disfuncionais consolidou-se como um dos dogmas fundamentais da brasilidade, do caráter nacional único do Brasil. $^{47}$

Ao longo das próximas décadas, esses ideais e ícones de uma identidade nacional unificada ganharam força, permeando $\mathrm{o}$ pensamento nacionalista da esquerda e da direita. A partir do final dos anos de 1950 até o golpe de 1964, acadêmicos de esquerda do Instituto Superior de Estudos Brasileiros (ISEB) desenvolveram um discurso de "autenticidade" versus "alienação" que estabeleceu o modelo para apreciar a produção cultural contemporânea. Suas teorias de uma autêntica cultura brasileira inspiravam-se em críticas de culturas e mentalidades colonizadas nos escritos de intelectuais contemporâneos de esquerda (como Frantz Fanon, Octave Mannoni, Jean-Paul Sartre e Georges Balandier), bem como de anteriores (especialmente Hegel e o jovem Marx). Tal como interpretado pelo ISEB, muito da cultura brasileira era "alienada". Em outras palavras,

45 MCCANN, Bryan. Hello, Hello Brazil: Popular Music in the Making of Modern Brazil. Durham, NC: Duke University Press, 2004; FRY, Peter. Feijoada e 'soul food': notas sobre a manipulação de símbolos étnicos e nacionais. In: Para inglês ver: identidade e política na cultura brasileira. Rio de Janeiro: Zahar, 1982; VIANNA, Hermano. The Mystery of Samba: Popular Music and National Identity in Brazil. Trad. John Charles Chasteen, Chapel Hill: University of North Carolina Press, 1999; BORGES, Dain. The Recognition of Afro-Brazilian Symbols and Ideas, 1890 - 1940. Luso-Brazilian Review, v. 32, n. 2, 1995, pp. 59 - 78.

46 MCCANN, Hello, Hello Brazil; VIANNA, The Mystery of Samba.

47 ANDREWS. Brazilian Racial Democracy, pp. $487-89$. 
os brasileiros - impulsionados por um sentimento de inferioridade resultante por uma posição periférica em um sistema mundial neocolonial - confiavam excessivamente em modelos estrangeiros nas suas tentativas de criar uma cultura nacional. Um autêntico "eu" brasileiro só poderia ser recuperado por meio de uma celebração dos produtos culturais que emergiram das condições sócio-históricas peculiares do Brasil, e não, como no caso do soul, copiando a cultura da metrópole. ${ }^{48} \mathrm{O}$ trabalho dos intelectuais de esquerda na década de 1950 e início dos anos 60, assim, adicionou à definição de brasilidade da Era Vargas o imperativo de defender essa visão nacionalista contra a penetração cultural estrangeira e imperialista.

Sob a ditadura militar, que começou em 1964, as ideologias de brasilidade e democracia racial assumiram um caráter ainda mais totalizante, de fato sufocante. Os governos militares tentaram fazer valer a imagem de um Brasil africanizado, racialmente harmonioso, em casa e no exterior, se antecipando ao desenvolvimento de uma política racial contestatória autóctone ou inspirada nos Estados Unidos ou na África. Estes objetivos os levaram a enfatizar a africanidade do Brasil nos termos de uma presença africana folclórica, remota e despolitizada, fortemente mediada pela mistura cultural e racial e dominada por processos de nacionalização. Em 1977, por exemplo, o Itamaraty enviou uma delegação de diplomatas, intelectuais, artistas, cineastas e dançarinos para representar o Brasil no Segundo Festival Mundial das Artes Negras (FESTAC II) em Lagos, na Nigéria. A publicação oficial do Itamaraty sobre a participação do Brasil no festival louvava (para o público brasileiro e africano) a inserção harmoniosa de traços africanos no Brasil, exibidos pela delegação principalmente através de manifestações como o samba e o candomblé. Mas esta publicação, intitulada $O$ impacto da cultura africana no Brasil, retratou a cultura africana como uma coisa do passado, já não fisicamente ligada à África ou mesmo, e necessariamente, às pessoas de ascendência africana no Brasil. Para o autor, o conservador crítico de arte Clarival do Prado Valladares, o "impacto" africano era uma espécie de colisão histórica 1985, p. 47.

48 ORTIZ, Renato. Cultura brasileira e identidade nacional. São Paulo: Brasiliense, 
entre as culturas que legaram ao Brasil uma sensibilidade cultural intangível e mística: ele escreveu sobre a "prototipia africana" nas formas culturais brasileiras e saudou "o lastro da cultura-de-base de origem africana". ${ }^{49}$ Até mesmo quando o governo brasileiro proclamou no exterior a (desencarnada) herança africana de sua nação, ele continuou cumprindo a legislação (aprovada em 1968) que proibia a discussão de questões raciais nos meios políticos, acadêmicos ou artísticos. ${ }^{50}$ Até o momento da publicação do artigo de Frias, as ideias sobre cultura brasileira, raça e identidade nacional estavam congeladas num estreito figurino de "autenticidade nacional" moldado por preocupações ideológicas extremas (embora inesperadamente sobrepostas) da esquerda e da direita.

\section{$O$ nacionalismo conservador e o desafio do soul à mestiçagem brasileira}

Até Frias publicar sua denúncia, a Polícia nunca tinha considerado que os bailes soul pudessem representar uma ameaça a essa política cultural oficial, contentando-se com a conclusão de que eles não cabiam em nenhuma de suas categorias consagradas de subversão. Apenas cinco dias após o relato sensacionalista de Frias aparecer no Jornal do Brasil, no entanto, o delegado da Polícia Militar Antonio Viçoso Cotta Gomes enviou uma carta preocupada a DGIE pedindo-lhes para investigar o soul, uma questão que considerou "de magna importância". Anexou o artigo de Frias, que, explicou, "causou-me impacto pelo sentido de oposição que, futuramente, poderá ser criado entre pessoas brancas e pretas. Incentiva-se a separação com o surgimento de várias atividades

49 VALLADARES, Clarival do Prado. O impacto da cultura africana no Brasil. Brasília: Ministério das Relações Exteriores / Ministério da Educação e Cultura, 1976, p. 234, 244.

50 AZEVEDO, Thales de. Democracia racial: ideologia e realidade. Petrópolis: Vozes, 1975 , p. 53. 
sociais exclusivistas, inicialmente de bailes onde é tocada a música 'SOUL' preferida dos pretos, citando-se o 'rock' como sendo a dos brancos". Gomes instou o DGIE a organizar uma investigação em torno de uma série de questões-chave. Quem, por exemplo, estava financiando a visita dos negros americanos ao Brasil, "cuja ideologia não conhecemos?". Não seria possível, continuou ele, que a "exclusividade do tipo de música, a uniformidade no vestir e no calçar, não viriam a constituir, mais tarde, um grupo também político e orientado no sentido de preconceito racial?". Finalmente, Gomes sem dúvida reagindo à foto de paredes grafitadas que abria o artigo de Frias - comentou a "ostentividade" com que o "movimento" tinha se apoderado do Rio, "divulgando sua programação através de cartazes e inscrições em muros e paredes, enfeiando a fisionomia da Cidade, além do dano, o que nem mesmo é permitido por ocasião da propaganda eleitoral". ${ }^{51}$ O soul estava desfigurando a face harmoniosa da cidade com a sua "blackitude" atrevida.

Embora tenha começado com um enfoque familiarizado com a agitação externa, a carta de Gomes mostra quão rapidamente e claramente ele percebeu o que os oficiais do DGIE não haviam vislumbrado totalmente: o potencial do soul como base para a transformação de identidades raciais e o subsequente ativismo racial. As linhas seguintes de Gomes revelam até que ponto a argumentação de Frias sobre o separatismo do Black Rio havia atingido sua meta, fomentando a percepção da ameaça do soul de um ataque simbólico à identidade mista e harmoniosa do Brasil. "É mister lembrar que em nosso país sempre houve harmonia entre brasileiros, independente de raça e religião. A miscigenação de nosso povo - branco, preto, índio - segundo Gylberto Freire [sic], em 'Casa Grande e Senzala', é um privilégio". ${ }^{52}$ Os historiadores da ditadura há muito ressaltam a amplitude com que seus funcionários abraçaram, e reforçaram, ideais nacionais de mestiçagem e tolerância racial, conforme descrito por Freyre. ${ }^{53}$ Mas, de fato, é raro ver um policial militar citando desafios a esses ideais como infrações em um relatório - literalmente

51 DGIE 252, p. 10, 22 de julho de 1976. Ênfase no original. 52 Ibid.

53 Por exemplo, SKIDMORE, Thomas. Race and Class in Brazil: Historical Perspectives. In: FONTAINE, Race, Class, and Power, p. 12. 
"policiando" essas idéias — e apoiando-se na obra de Freyre como fundamento simbólico da segurança nacional.

Gomes não foi a única figura da direita política a ver o artigo de Frias como um sinal de alerta. No ano seguinte, comentaristas com uma firme postura conservadora em relação à cultura nacional continuaram a expressar sua consternação com o fenômeno soul. Em um artigo de opinião para o jornal carioca $O$ Globo, intitulado “'Black power' no Brasil”, o editorialista Ibraim De Leve informava a seus leitores que "um grupo da área musical brasileira está tentando lançar o movimento 'Black Power' no Brasil'. De Leve, como antes dele a DGIE, estava inclinado a ver o soul como um "movimento" político organizado, embora ele levasse esse diagnóstico a um nível absurdo:

\begin{abstract}
O líder é o cantor Gerson King Combo e o vice-líder Tony Tornado. A tônica do movimento é lançar o racismo no país, como existe nos States. Eles chamam uns aos outros de 'brother', e o cumprimento é com o punho fechado para o alto. Nos shows que estão promovendo no Rio e em São Paulo conseguiram a presença de 10 mil pessoas. Os brancos são evitados, mal tratados e até insultados. [...] Nos espetáculos os negros aproveitam a oportunidade para agitação, jogando negros contra brancos e fazendo uma preleção para o domínio da raça no Brasil, a exemplo do que acontece nos States. ${ }^{54}$
\end{abstract}

Embora exagerada na percepção da organização formal do movimento (com "líder" e "vice-líder") e reacionária na aversão à "agitação" negra de inspiração norte-americana, a alarmada intervenção de De Leve sugere que ele percebera no soul o poder de desestabilizar seriamente o status quo racial do Brasil — ou seja, de atacar a dominante e acalentada ideia de que (como ele mesmo sublinhou) "no Brasil não existe racismo". Quaisquer diferenças sociais existentes, De Leve combateu rapidamente com um

54 DE LEVE, Ibraim. 'Black power' no Brasil. O Globo, $1^{\circ}$ de outubro de 1977. 
argumento conservador familiar, não foram causadas por discriminação racial, mas de classe: "Existem as pessoas que alcançam posições mais elevada e outras menos". 55

De Leve não estava sozinho em sua análise do soul como um movimento racista, fundamentalmente oposto aos valores brasileiros básicos de unidade e harmonia racial. Um autor anônimo, também escrevendo em $O$ Globo vários meses antes de De Leve, declarou: "Não se pode considerar autêntico, nem positivo, qualquer movimento - musical, esportivo ou que outro pretexto tenha - que, em nome de uma manifestação artística, ou mesmo de simples entretenimento, procure dividir a sociedade brasileira com uma cunha racial." Ele intitulou seu artigo "Racismo", sugerindo a ideia conservadora comum de que qualquer manifestação de base racial por brasileiros negros era discriminação racial (às avessas) e, portanto, um ataque ilegítimo e imoral à unidade racial do Brasil. Para construir esse argumento, o escritor contou com a noção de alienação da esquerda, mas reconfigurou-a para falar de identidades raciais, ao invés de modas ou mercantilismo:

É próprio da juventude escolher os seus próprios meios de expressão; e é comum que esses meios sejam esdrúxulos, excêntricos. Assim, não é por seus aspectos pitorescos, beirando às vezes o grotesco, que se deve condenar esse movimento batizado de "soul", ou, na versão carioca, de "Black Rio". O problema não está nas roupas, nos sapatos, ou nos apelidos. Mas está no que se esconde atrás de tudo isso: uma visão alienada da realidade, artificialmente estimulada por interesses nitidamente comerciais, e tendo por base um indisfarçado racismo. $^{56}$

O problema com o soul não estava em seu suposto desafio à autonomia de uma cultura exclusivamente brasileira, à tradição

55 Ibid.

56 Racismo, O Globo, 26 de abril de 1977. 
política ou à economia nacional; mas no fato de que era "alienado" em sua própria visão da "realidade" das relações raciais que subjaz a esses construtos. Esta versão "alienada" das relações raciais, é claro, era ao estilo do "racismo" americano, que para o autor, evidentemente, não significava o racismo que os brancos praticam contra os afro-americanos. Pelo contrário, ao denunciar a emulação "racista" dos brasileiros com os negros norte-americanos, este autor pretendeu criticar tanto a sugestão de que o sistema racial do Brasil deveria ser comparado ao dos Estados Unidos, quanto a ideia a isso relacionada de que os brasileiros afrodescendentes deveriam procurar remediar sua (percebida) exclusão através da adoção da política racial contestatória de seus pares norte-americanos.

O escritor anônimo de $O$ Globo alegou ainda que o samba era o autêntico reflexo de harmonia racial do Brasil, em contraste com a alienação do soul, este, uma interpretação equivocada e racista de um problema estrangeiro. "Nos próprios locais onde hoje se ouvem os ritmos importados do 'soul' soam em outras horas as batidas do samba, em testemunho irrespondível de que a música e a diversão, no Brasil, não têm fronteiras raciais". ${ }^{57}$ Não demorou muito a Gilberto Freyre, o porta-voz oficial da teoria da excepcionalidade racial brasileira, juntar-se a este debate. Seus pontos de vista ressoaram mais próximos aos pensadores da direita política, pois em seus últimos anos Freyre tinha-se tornado cada vez mais aliado das ditaduras militares no Brasil, Portugal e África portuguesa. "Teriam os meus olhos me enganado?", Freyre escreveu com falsa modéstia, "Ou realmente li que, dos Estados Unidos, estariam chegando ao Brasil - se é que já não se encontram — vindos da tradicionalmente muito amiga República dos Estados Unidos da América do Norte, americanos de cor encarregados - por quem? - de convencer brasileiros, também de cor, que suas danças e seus cantos africanos deveriam ser de melancolia e revolta?". ${ }^{\circ}$

A elite conservadora do Brasil, incluindo o próprio Freyre, transformou os ideais freyrianos de mistura racial e cultural numa

57 Ibid.

58 Gilberto Freyre, (de "Atenção brasileiros!” do Diário de Pernambuco, 15 de maio de 1977) citado em Black Rio, Um e Meio, 20-21 de novembro de 1977. 
ferramenta para questionar a legitimidade de uma forma cultural que sugeria um movimento ou consciência racial independentes. Nesta visão, o samba representava a harmoniosa incorporação pela nação dos povos e das culturas africanas através da mestiçagem, em contraste com a consciência racial separatista e estrangeira do soul. A Polícia secreta, no rastro da alarmada carta de Gomes, recortou estes artigos conservadores e anexou-os a seus crescentes dossiês sobre o soul. "As autoridades estão atentas a esse movimento", como Ibraim De Leve previdentemente expressou, "pois pode se tratar de problemas de segurança nacional". 59

\section{O nacionalismo de esquerda e o alienado soul}

A própria Lena Frias era afrodescendente, e há momentos em que seu artigo parece prestes a usar a ascensão do Black Rio para expor a segregação racial no Brasil. ${ }^{60}$ Às vezes, relata de forma neutra ou até mesmo positivamente as ideias e atitudes dos dançarinos, chegando a afirmar que o Black Rio era uma consequência natural das realidades sociais de segregação no Brasil, e que a repressão ao soul era racista. Mas de modo geral, sua visão política ecoava as ideias da esquerda-nacionalista do ISEB. Frias passou grande parte de sua carreira como jornalista defendendo ferrenhamente os ícones de uma brasilidade misturada, como samba e carnaval, e seu artigo voltava repetidamente à ideia de que a música soul era uma forma cultural alienada. ${ }^{61} \mathrm{O}$ subtítulo do artigo de Frias, "O orgulho (importado) de ser negro no Brasil", capta o seu argumento de que o movimento acabou por ser desviado e não

59 DE LEVE. 'Black power' no Brasil.

60 Sobre Frias, ver SANSONE, Blackness without Ethnicity, p. 115.

61 Sobre a posição política de Frias, ver a carta que ela divulgou após ser demitida do Jornal do Brasil em 2001, republicada em Opinião: De que morreu Lena Frias? Website da Associação de Músicos, Arranjadores e Regentes, www.amar.art.br/opiniao/opiniao_20.htm (acessado em 12/11/07). 
conseguiu encarnar uma política racial autêntica ou sequer reconhecível. Ela e outros escritores de posição política semelhante publicaram uma série de artigos nesse sentido, que a Polícia secreta também recortou e levou em conta em suas tentativas de esclarecer o potencial subversivo do fenômeno.

Em consonância com outros críticos culturais da esquerda, Frias viu um ligação estreita entre a natureza importada da soul music e seu foco em símbolos estilísticos comerciais e, portanto, triviais. $\mathrm{O}$ fenômeno soul, escreveu ela, era uma mania em estilos de vestuário e música, trazida (separada de seu contexto político) dos Estados Unidos. Frias retratava seus sujeitos como fãs obcecados que não mediam esforços para compor trajes "em modelos americanos" e que, como se mecanicamente, "sabem tudo sobre o soul, detalhes históricos, épocas de lançamentos de discos, de conjuntos e cantores norte-americanos". Os bailes soul, ela mostrou, muitas vezes incluíam concursos cujo objetivo explícito era a imitação, como as "Noites do Shaft" do Renascença, que prometiam um prêmio a quem mais se assemelhasse a Isaac Hayes. Para Frias, a imitação impensada por trás do Black Rio o fazia um pouco menos perigoso como um movimento racial divisionista. Seu comercialismo minava ainda mais qualquer consciência política. "No seio dessa massa Black", Frias relatava, "movimentam-se empresários, discotecários, comerciantes de discos [...], comerciantes de sapatos [...] produtores de discos", e acima de tudo, o elemento fundamental do fenômeno soul, os conjuntos de música. Como o DJ e produtor de soul, branco, Ademir Lemos explicou a Frias, os grupos de soul faziam até duzentos cruzeiros por festa, "uma loucura [...] uma renda que um jogo, se não tiver Vasco ou Flamengo, não atinge". 62

Uma gama de colunistas de esquerda de suplementos culturais tradicionais, revistas populares e revistas de música imediatamente absorveram e amplificaram a crítica de Frias à natureza importada e comercial do soul. O Jornal do Brasil, que havia publicado a reportagem de abertura de Frias, deu seguimento, um par de semanas mais tarde, com a matéria intitulada "Soul: sociologia e mercado". Nela, o autor Tárik de Souza (um jovem jornalista branco

62 FRIAS, Black Rio. 
que também escrevia para o Jornal da Música e para $O$ Pasquim, revista esquerdista de humor e política) contrastou a complexa história do jazz, funk e soul music nos Estados Unidos com as compilações dirigidas ao público brasileiro. Souza considerou as gravações de soul disponíveis no Brasil "apenas 10\% de alma e $90 \%$ de planejado marketing". 63 Tarlis Batista, escrevendo sobre soul para a revista Manchete, falou com desdém da "fidelidade" canina do público soul, um "público [...] sempre muito fiel às iniciativas do grupo", assegurando múltiplos "benefícios" não apenas para "gravadoras, sapatarias e lojas de disco", mas também para fabricantes de acessórios que enfeitavam as roupas dos negros: "bengalas, cachimbos, chapéus, óculos, bonés, jóias e pentes de fabricação especial". ${ }^{64}$ Estas narrativas das façanhas de pequenos e grandes empresários consideravam o fenômeno soul um enorme embuste comercial, com os jovens afrodescendentes cariocas da classe trabalhadora como vítimas inocentes (e ignorantes).

Além de criticar o soul como comercializado, estes artigos explicitamente apresentavam o mercantilismo como prova contra qualquer possível consciência política ou racial entre os seus dançarinos. O compositor de samba Candeia (afrodescendente como Frias), então um dos líderes de uma escola de samba alternativa (Quilombo) que notoriamente se esforçava para evitar a comercialização e as ligações com o Estado, expressou esta visão do soul em uma entrevista para o suplemento dominical de cultura do Jornal do Comércio, Um e Meio: "Por detrás disso tudo, uma verdadeira formação dirige o trabalho; os negros que fazem parte do movimento são o que se pode chamar de inocentes úteis. Eu vim a saber que, na maior parte, os donos dos equipamentos de som são todos meninotes da Zona Sul”. ${ }^{65}$ A referência à Zona Sul, quer entendida simplesmente como alusão à situação econômica (como Candeia explicitamente declarou), quer como referência cifrada de

63 SOUZA,Tárik de. Soul: Sociologia e mercado. Jornal do Brasil, 27 de agosto de 1976. Este ecoa vários artigos contemporâneos no Jornal da Música, em que os autores procuraram distinguir entre o soul "real" e as deformações apócrifas; por exemplo,"O que é Soul de verdade?", Jornal da Música, 11 de novembro de 1976.

64 BATISTA, Tarlis. Os Blacks no embalo do soul. Manchete, 11 de setembro de 1976. 65 Black Rio, Um e Meio, 20 - 21 de novembro de 1977. 
branquitude, põe claramente em questão a legitimidade do soul enquanto forma autenticidade expressão cultural ou política negra. Para Tarlis Batista, o soul era uma "adesão às fórmulas musicais fabricadas em linha de montagem, no exterior", e "dificilmente poderia sugerir algo além do mero conformismo de uma gente simples, despreparada talvez para resistir ao bombardeio dos modismos pela mídia". Foi o que Batista concluiu graças, em parte, a uma conversa com um jovem negro, que supostamente "mal conhece também o significado de algumas das expressões em inglês que repete a todo mundo" - o que ele chamava de "mera repetição de palavras estrangeiras numa pronúncia equivocada". Da mesma forma, Lélia Gonzalez, pensadora marxista e feminista negra, disse a Batista, em 1976: "Tenho certeza de que não se trata de uma tomada de posição do negro, mas só uma identificação provocada pelo fenômeno da cultura de massa, que o americano faz muito bem". 66 Para algumas pessoas negras como Frias, Candeia ou Gonzalez, em meados da década de setenta o nacionalismo cultural esquerdista ainda parecia um caminho promissor para tratar de questões de raça, embora isso fosse começar a mudar na segunda metade da década.

As acusações mais contundentes de inautenticidade do soul vieram da irreverente revista de esquerda $O$ Pasquim. Em um artigo, o crítico de música Roberto M. Moura escreveu que "se trata de uma insidiosa campanha publicitária, neo-colonialista, que visa apenas criar o sujeito que vai consumir o excedente de uma produção de fora daqui. [...] Fica claro que este agrupamento social não está pensando; está sendo pensado. De fora para dentro. Se de repente, vier uma ordem concitando a um outro tipo de roupa, ele tira a jaqueta e descalça o pisante". 67 Outro artigo d'OPasquim, intitulado "Safari", descreveu a visita do autor a um baile soul como uma caminhada na África mais profunda (ecoando o tema etnográfico de Frias). Ele se referiu aos bailarinos de soul que conheceu como servos de um líder tribal tirânico (falando um pidgin de Português intercalado com frases

66 BATISTA. Os Blacks no embalo do soul. Ver também TINHORÃO, J. R. Protesto 'Black' é fonte de renda 'White'. Jornal do Brasil, 14 de junho de 1977.

67 MOURA, Roberto M. Carta aberta ao Black-Rio. O Pasquim, 2 - 8 de setembro de 1977. 
em inglês, como "oh yeah"), que por sua vez idolatrava os supremos deuses brancos do soul, os executivos de gravadoras. ${ }^{68} \mathrm{Se}$ os comentaristas de direita temiam que o soul fosse perigoso pelas formas de revolução social que podia inspirar, especialmente revolução racial, os de esquerda o lamentavam pelo modo como sua natureza comercial desviava da autêntica atividade revolucionária baseada em classe.

Como os críticos conservadores, escritores de esquerda articularam sua rejeição ao soul mais claramente em contraste com o samba. Enquanto os críticos de direita viam o samba como expressão da estabilidade social brasileira, muitos na esquerda viam-no como a única expressão verdadeira, progressista, de uma identidade nacional africanamente modulada. Moura, o escritor do esquerdista $O$ Pasquim, prosseguia suas invectivas contra o soul com a afirmação de que, se, em vez de participar em "uma transação [...] na base do inconsciente coletivo arrastando tudo", essa massa de gente realmente pensasse por si mesma, voltariam as energias que estavam desperdiçando no soul para a tarefa de revitalizar os verdadeiros valores e cultura negros no Brasil. Isto é, "então este agrupamento social teria que se voltar para o samba".69 Muitos escritores de esquerda, como os defensores nacionalistas da cultura popular em toda a América Latina, acreditavam no poder político do samba como uma forma de expressão popular autêntica. Mesmo aqueles que poderiam ter imaginado uma posição política ou cultural especificamente negra do povo brasileiro negaram o soul como um modismo comercial importado, um artefato apócrifo do imperialismo cultural americano. Na melhor das hipóteses, argumentavam que o fenômeno conhecido como Black Rio fora uma bobagem e politicamente ineficaz; na pior, representava uma traição ao verdadeiro patrimônio cultural do Brasil por pessoas negras que, abraçando o soul estrangeiro em vez do samba nacional, estavam se esquivando de seus deveres como prestimosos zeladores de uma herança afro-brasileira apropriada, autêntica.

68 BLANC, Aldir. Safari. O Pasquim, 5 - 11 de agosto de 1977.

69 MOURA, Carta aberta ao Black-Rio. O fim da citação de Gonzales a Batista também sugere um retorno ao samba. BATISTA, Os Blacks no embalo do soul. 


\section{Do perigo ao escárnio: a polícia secreta veicula a esquerda}

Ironicamente, foi o escárnio desses escritores de esquerda (em vez do alarme dos conservadores) que acabou influenciando as investigações da Polícia secreta sobre o soul. Enquanto liam Frias e outros escritores de esquerda, os investigadores da Polícia inicialmente pesavam duas idéias: que a origem estrangeira do soul fazia dele uma ameaça como movimento racial, e que sua natureza comercial e origem estrangeira o faziam politicamente ineficaz. Em setembro de 1976, um pedido de busca resumia os "dados conhecidos" sobre o soul. Citando os artigos de Frias, Souza e Batista, o documento explicava que o soul "parece tratar-se de um movimento centrado em torno de elementos da raça negra, visando aparentemente a interesses comerciais a exemplo do que ocorre nos Estados Unidos da América de onde busca inspiração". Apesar da referência a mercantilismo neste relatório, a ameaça simbólica ainda pairava. Na linguagem dos investigadores da Polícia, dançarinos de soul já não eram "pessoas de cor", mas ativistas raciais "negros". O soul, o relatório literalmente sublinhou, "explora, de certa forma, o orgulho da 'negritude', o confronto entre brancos e pretos e a rivalidade social e econômica entre a Zona Norte e a Zona Sul do Rio de Janeiro". Ecoando o delegado da Polícia Militar Cotta Gomes, o autor concluía que o soul "pode ser facilmente explorado para outros fins que não os até agora apresentados". ${ }^{70}$

Os arquivos da Polícia secreta desse período mostram uma renovada agitação de atividades. Assiduamente os policiais procuravam em seus arquivos informações sobre qualquer pessoa ligada ao movimento - de DJ's e cantores como Monsieur Lima, Tony Tornado, Big Boy e membros de suas equipes, a jornalistas como Tárik de Sousa, Lena Frias, Tarlis Batista e o fotógrafo Almir Veiga, e até produtores, como Ademir Lemos. Apesar do fato de que várias de suas investigações sobre estes indivíduos mostrassem ligações a grupos comunistas, os investigadores não identificaram

70 DGIE 250, p. 734, 13 de setembro de 1976. Ênfase no original. 
essas ligações como a principal ameaça. ${ }^{71}$ Em vez disso, seguindo o exemplo dos comentaristas de direita, eles se concentraram no que parecia preocupar a mídia impressa em relação ao soul: suas implicações "psicossociais" e potenciais rivalidades raciais e de classe, bem como as implicações não especificadas de que o movimento explorava a "corrupção policial". ${ }^{72}$

Mas a Polícia minimizava cada vez mais a conotação racial do soul como mera manipulação de mercado, refletindo, em última análise, a influência dos escritores de esquerda cujos artigos eles também tinham lido e guardado. Em um relatório de outubro de 1976, por exemplo, eles explicaram que "Apesar de o nosso movimento 'Black Power' assumir certo caráter contestatório e discriminatório [...] o objetivo precípuo desses grupos continua sendo o de faturarem, não lhes importando o tipo étnico dos admiradores da música que apresentam". ${ }^{73}$ Em outras palavras, DJ's negros tinham uma audiência negra porque sabiam como explorar o nicho comercial lucrativo da soul music. Marketing, mais do que uma política racial explícita, explicava o caráter todo negro das danças. Esse tipo de mercantilismo, um relatório do fim de agosto 1976 explicava, não era nem exclusivo dos empreendedores negros; acontecia também nas discotecas da Zona Sul. "O objetivo destes discotecários seria criar núcleos de diversão onde somente estes privilegiados conseguiriam organizar bailes e obter um público dirigido [ie. selecionado com base na cor], utilizando assim tanto brancos como negros em objetos de consumo [e] centralizando através da música os polos de diversão de uma determinada faixa de público". ${ }^{74}$ Embora jornalistas da esquerda nacionalista pudessem ter dito isso em melhor português, seus sentimentos não poderiam ser mais alinhados.

71 Eles chamaram um membro de um conjunto musical não especificado de "comunista" (de Belo Horizonte) e acusaram outro de ligações com grupos de "camponeses comunistas" em Minas Gerais. DGIE 252, pp. 66 - 64, 9 de novembro de 1976.

72 DGIE 252, pp. 72 - 70, 19 de outubro de 1976. A afirmação, neste relatório, de que os artigos de Frias, Veiga, Batista e de Souza exploravam questões de "corrupção policial" em relação ao movimento é vaga; talvez estivessem se referindo ao relato de Batista do repetido interrogatório da Polícia a Paulo Santos sobre a escolha do nome "Black Power" para o seu grupo.

73 DGIE 252, pp. 69 - 67, 5 de outubro de 1976; ver também DGIE 250, pp. 8 - 7, 23 de agosto de 1976 .

74 DGIE 250, pp. 728 --27, 23 de agosto de 1976. 
O relatório da Polícia que encerrou as investigações sobre o soul ecoou ainda mais a linguagem dos comentaristas de esquerda. Ele não só concluiu que qualquer confronto entre negros e brancos brasileiros era, em última análise, uma questão de marketing de música e moda, em vez de uma política consciente, como também traduziu o lamento da esquerda de que o soul deslocava a consciência revolucionária real, em uma espécie de alívio presunçoso de que os dançarinos de soul nunca seriam capazes de constituir uma ameaça real ao Estado. O relatório declarava que, apesar de o soul "abriga[r] algum sentimento contestatório e racista", o fenômeno ficava, "porém[,] ainda sem grandeza nem profundidade, não logrando contextura sociopolítica". O que a Polícia inicialmente vira como um potencial elo musical e cultural com estilos Black Power, ela agora explicava em termos condescendentes:

A música "soul" é originária dos bairros negros norteamericanos e sua origem conhecida remonta ao período da escravidão nos Estados Unidos. Já deturpada por fatores diversos e pela influência de outros ritmos, mantém relação íntima com o movimento "Black Power" americano, por fidelidade à origem comum etnológica, e é delirantemente aplaudida por seus adeptos, [...] todos de cor. [...] Os negros brasileiros, por atavismo, se mostram notavelmente sensíveis à música dita "soul". Aqui no Rio muitos deles, em parte por emulação, em parte por esnobismo, mas visando sempre a obtenção do lucro, se vêm organizando em grupos ou conjuntos musicais a que dão nomes pitorescos ou bombásticos. ${ }^{75}$

Às críticas da esquerda ao mercantilismo e à imitação ridícula do soul, o autor adicionou um novo termo - atavismo - tirado do repertório da antropologia criminal do século XIX, sugerindo

75 DGIE 252, pp. 69--67, 5 de outubro de 1976. Embora as investigações policiais sobre o soul continuassem (ainda que de forma menos intensa) até meados de novembro, este relatório reaparece em 25 de novembro de 1976 como a palavra final da Polícia sobre o movimento (DGIE 252, pp. $63-61$ ). 
algum tipo de resposta primal das pessoas de ascendência africana à música negra. Policiar a imagem de democracia racial do Brasil, ao que parece, envolvia interpretar quaisquer desafios não apenas como perigosos ou ilegítimos, mas, em última análise, como irrelevantes.

\section{Soul Power? Ativistas, DJ's e dançarinos avaliam a política do Soul}

Enquanto jornalistas e policiais investigavam o fenômeno soul, eles entrevistaram e citaram dezenas de participantes no movimento. Suas vozes emergem com uma notável nitidez dos densos debates ideológicos. Produtores, DJ's, dançarinos, ativistas negros e intelectuais muitas vezes sugeriram, direta ou indiretamente, que o soul fosse um espaço produtivo que desafiava as estreitas ideias de cidadania negra codificadas em visões dominantes da cultura nacional - e em particular do samba.

Em seus comentários à imprensa, entusiastas do soul foram rápidos em apontar os pressupostos racistas por trás das visões do soul como a antítese da "autêntica" cultura afro-brasileira. Em uma entrevista para a revista semanal Veja, o DJ Dom Filó do Soul Grand Prix questionou:

Por que se aceita com toda a naturalidade que a juventude da zona sul se vista de jeans, dance o rock, frequente discoteca e cultue Mick Jagger, enquanto o negro da zona norte não pode se vestir colorido, dançar o soul e cultuar James Brown? [...] Por que o negro da zona norte deve aceitar que o branco da zona sul (ou da zona norte) venha lhe dizer o que é autêntico e próprio ao negro brasileiro? Afinal, nós que somos negros 
brasileiros nunca nos interessamos em fixar o que é autêntico e próprio ao branco brasileiro. ${ }^{76}$

Dom Filó, como sugerem esses afiados comentários, era um defensor do soul particularmente eloquente e instruído. Engenheiro de profissão, Filó passou grande parte dos anos 70 envolvido no ativismo cultural negro, principalmente com grupos de teatro e dança. ${ }^{77}$ Mas os jovens dançarinos de soul, de variadas origens sociais e com diferentes níveis de educação, frequentemente faziam críticas semelhantes à hipocrisia racial a respeito do soul em suas entrevistas à imprensa nacional. José Alberto Carneiro, mecânico carioca de 19 anos, disse a Lena Frias: "Poxa, eles implicam com tudo que a gente faz. Até com o nome da equipe Black Power, a que eu mais gosto, eles implicam. Se fosse white power eles achavam tudo certo." ${ }^{\text {"78 }}$ Sob este prisma, até mesmo a frequente teimosia de dançarinos e DJ's de que o soul não era político revela uma astuta crítica política às inconsistências da sociedade sobre raça. Como DJ Nirto do Soul Grand Prix disse a Lena Frias, "Esse negócio é muito melindroso, sabe? Poxa, não existe nada de político na transação. É o pessoal que não vive dentro do soul e por acaso passou e viu, vamos dizer assim, muitas pessoas negras juntas, então se assusta. Se assustam e ficam sem entender o porquê. Então entram numa de movimento político. Mas não é nada disso [...] é curtição, gente querendo se divertir". ${ }^{79}$ Ao manipular os significados da política (no caso de Nirto, intencionalmente definindo-a no mesmo sentido estreito da Polícia secreta), os participantes do soul foram capazes de desviar-se simultaneamente das críticas sociais ou da atenção da Polícia, ao tempo em que marcavam posição política sobre o funcionamento do racismo brasileiro. ${ }^{80}$

76 Black Rio. Veja, 24 de novembro de 1976.

77 Ibid.

78 FRIAS. Black Rio. Ênfase no original.

79 Ibid.

80 Por exemplo, embora a Polícia secreta citasse a fala da estrela do soul, Tony Tornado, sobre a natureza apolítica do soul, em outro relatório ela menciona tê-lo levado a interrogatório porque "atuou no Teatro Copacabana, quando aproveitou a oportunidade para lançar algumas ideias sobre a discriminação racial no Brasil." DGIE 252, p. 66, 9 de novembro de 1976. 
Algumas das denúncias mais veementes de racismo nas reações públicas ao soul vieram de membros do então nascente movimento negro. No Rio de Janeiro, como em outras grandes cidades brasileiras, durante o período da distensão, jovens negros (cada vez mais representados entre os estudantes universitários, em meados da década de setenta) organizaram associações com vistas a desenvolver uma política que, ao contrário da esquerda tradicional, tratava especificamente da questão de raça. Grupos como a Sociedade de Intercâmbio Brasil-África (SINBA) ou o Instituto de Pesquisas das Culturas Negras (IPCN), ambos ligados à Universidade Cândido Mendes, redigiam listas de leitura, realizavam aulas e passeatas e publicavam boletins expressando sua política racial contestatória. ${ }^{81}$ Enquanto a esquerda e a direita mantinham ideias igualmente totalizantes de cultura nacional e "autenticidade", baseadas em um passado afro-europeu híbrido, ativistas e intelectuais no movimento negro começaram a criticar as ideias de democracia racial e mestiçagem como "mitos" opressivos ofuscando uma realidade racista. $^{82}$

Os jovens do SINBA e IPCN estavam assim perfeitamente preparados a fazer análises críticas da rejeição generalizada da sociedade ao soul. Escritores do jornal militante do SINBA, por exemplo, perguntavam por que os críticos eram tão ágeis em negar o soul, uma forma especificamente negra de lazer, como "alienado", enquanto os principais filmes e a música norte-americanos inundavam livremente a mídia brasileira. A ideia de que os dançarinos de soul eram alienados, eles argumentavam, mascarava a discriminação, tanto da esquerda como da direita, contra uma forma cultural negra. ${ }^{83} \mathrm{Sem}$ discutir se o soul era um movimento autêntico rumo à consciência racial, intelectuais do movimento negro também salientaram o valor político dos desafios do soul às expectativas culturais dos nacionalistas. Se "os zelosos defensores da 'democracia racial

81 Ver TURNER. Brown into Black; MITCHELL. Blacks and the abertura democrática; HANCHARD. Orpheus and Power; GONZALEZ, Lélia. O Movimento Negro na última década. In: GONZALEZ, Lélia e HASENBALG, Carlos. Lugar de negro. Rio de Janeiro: Marco Zero, 1982.

82 GONZALEZ. O Movimento Negro na última década, p. 34.

83 Por que o Black-Rio incomoda? Jornal SINBA, julho de 1977. 
brasileira' procuraram de todas as maneiras ridicularizar o movimento, acusando a rapaziada de racismo [...]," explicaram os redatores do SINBA em outro dos muitos artigos sobre o soul, foi precisamente pela forma "espontânea[,] inconsciente [e] audaciosa como a juventude negra botou na cara da nossa 'boa sociedade' a questão dos profundos problemas de relações raciais no Brasil". ${ }^{84}$

Alguns militantes alegaram ainda que os discursos de autenticidade e alienação dos críticos serviam especificamente para controlar a ascensão dos negros na sociedade brasileira. $\mathrm{Na}$ sua entrevista a Veja, por exemplo, Dom Filó questionou retoricamente, "Por que o negro tem que ser o último reduto da nacionalidade ou da pureza musical brasileira? Não será uma reação contra o fato de ele haver abandonado o morro? Contra uma eventual competição no mercado de trabalho?". ${ }^{85}$ Para Filó, o mercantilismo que sugeriu a Frias ou à Polícia que o soul fosse apolítico era de fato o seu aspecto politicamente mais desafiador. Os extensos relatos de Frias e de outros sobre as façanhas dos fornecedores de moda negra, grupos de DJ e empresários de música revelaram uma economia próspera e bem organizada por e para os afrodescendentes. Os empresários que criaram essa economia ressentiam-se do argumento de que o seu sucesso, ao contrário do sucesso dos brancos na indústria do entretenimento estabelecida, representava um desvio doentio do papel folclórico que lhe era adequado: dançar samba nas favelas. De fato, vários estudiosos têm sugerido que essa entrada visível e bemsucedida de operários brasileiros negros em um mercado de bens e serviços de lazer (como empresários e consumidores) foi uma das características que fizeram o soul tão chocante para os brasileiros tradicionais, que geralmente viam aos afrodescendentes, principalmente, como pobres e excluídos desse mercado. ${ }^{86}$

Embora fizessem menos sucesso do que DJ's e produtores, os dançarinos de soul também não eram das favelas mais pobres do Rio;

84 Descansem em paz. Jornal SINBA, abril de 1979.

85 Black Rio. Veja, 24 de novembro de 1976.

86 MCCANN. Black Pau, p. 84; MONTEIRO. O ressurgimento do Movimento Negro, pp. 71-72. Para uma análise das propagandas contemporâneas e a completa exclusão dos negros como consumidores ou empresários, ver HASENBALG, Carlos. O negro na publicidade. In: GONZALEZ e HASENBALG (orgs.). Lugar de negro, pp. $103-14$. 
eles vinham de bairros populares da cidade. Frias descreveu os "blacks" como pessoas com empregos de algum modo estáveis, embora humildes: eram empregados domésticos, carregadores, estafetas, mensageiros, vendedores, ambulantes e trabalhadores em empregos temporários (e estudantes, como já mencionado). ${ }^{87}$ Por conta de seus recursos limitados, os dançarinos de soul combinavam consumo e criatividade para criar seu estilo. Embora "as despesas com os sapatos [plataformas] não deixassem muita margem a luxos complementares", os aficionados do soul conseguiam completar seu almejado look "exótico" com objetos caseiros como "camisetas toscamente pintadas a mão" ou "velhos paletós bordados com fraseschave da soul music". ${ }^{88}$ Visto como um empreendimento comercial negro sustentado por entusiasmados consumidores negros, o Black Rio - longe de ser apolítico - pode ser lido como uma forma de política importante e significativa, em que a liberdade de consumir estava ligada à demanda de uma forma moderna de cidadania. ${ }^{89}$ Como Bryan McCann mostrou, participar de bailes soul permitia a jovens negros de toda a periferia do Rio, pelo menos, invadir as casas noturnas chiques e instituições culturais respeitáveis da Zona Sul, transgredindo as fronteiras sociais e espaciais. ${ }^{90}$

Os participantes nos bailes expressavam, ainda, uma percepção de que a sua nova identidade comum, como consumidores de cultura negra, era atraente porque lhes permitia assumir a sua herança africana de uma forma que comunicava distinção e orgulho, em vez de mistura. ${ }^{91}$ Como explicou um dançarino a Lena Frias, quando perguntado por que dançava soul: "Eu não sei explicar. É meu. É black. Vem do sangue e do coração." ${ }^{92}$ Ainda que não represente uma política articulada de raça, este tipo de resposta

87 FRIAS. Black Rio; e Gonzalez. "O Movimento Negro na última década".

88 FRIAS. Black Rio. Para saber mais sobre roupas soul feitas em casa, ver GIACOMINI. A alma da festa, $193-94$.

89 Cf. CANCLINI, Néstor García. Consumers and Citizens: Globalization and Multicultural Conflicts. Minneapolis: University of Minnesota Press, 2001, e YÚDICE, George. The Expediency of Culture: Uses of Culture in the Global Era. Durham, NC: Duke University Press, 2003.

90 MCCANN. Black Pau, pp. $84-85$.

91 Ver TURNER. Brown into Black, e MITCHELL. Blacks and the abertura democrática.

92 FRIAS. Black Rio. 
(comum a muitos dançarinos) sugere que o soul fosse significativo para muitos como fonte de identificação racial e pessoal. Também sugere que o soul repercutisse sentimentos positivos de vínculo com os povos e as culturas da diáspora africana (uma conexão que este jovem dançarino expressou como vindo do "sangue", mas que a Polícia secreta havia interpretado como "atavismo"). ${ }^{93}$

Os jovens militantes do movimento negro, em geral, acreditavam, com otimismo, que os sentimentos positivos de conexão mútua gerados através do soul pudessem ajudar a unir as pessoas em torno de uma identidade negra contestatória. Para Carlos Alberto Medeiros, um ativista do IPCN, o soul era oportunidade de "um trabalho cultural fértil junto aos jovens negros [...] um trabalho que contribuirá para o surgimento de uma identidade negra brasileira, tentada [...] sem sucesso, através do samba". Ecoando as opiniões dos comentaristas da direita (embora lhes dando valência política oposta), Medeiros identificava o samba como uma forma cultural que representava a assimilação racial e cultural. Ele via o soul como uma forma cujo estilo distinto poderia eventualmente vir a ser a pedra de toque de uma identidade solidamente negra, não viciada pela vergonha internalizada ou a atração pelo branqueamento individual:

Os adolescentes preferiram adotar como sua a imagem (obviamente exagerada e distorcida) que lhes transmitiam seus irmãos do Norte. E quem quer que se preocupe com esses jovens - e não apenas com essa coisa tão difusa e diversamente definida, que é a cultura brasileira (roubada dos negros) - não pode negar os efeitos benéficos da nova imagem sobre pessoas que hoje não se envergonham mais de se olhar no espelho. É claro que dançar soul e usar roupas, penteados e cumprimentos próprios não resolve, por si, o problema básico de

93 Vale a pena notar que a mania brasileira do soul aconteceu num contexto de "proliferação de formas mercantilizadas de cultura popular afro-americana em todo o Terceiro Mundo, com forte ressonância especialmente nas nações africanas e caribenhas pós-coloniais." DUNN. Brutality Garden, p. 178. 
ninguém. Mas pode proporcionar a necessária emulação para que se unam e, juntos, superem suas dificuldades. ${ }^{94}$

Foi o grupo de Medeiros, o IPCN, que organizou a exibição de Wattstax no Museu de Arte Moderna, no centro da cidade, como parte das comemorações de seu primeiro aniversário. Os membros do grupo frequentemente tentavam realizar também palestras nos bailes soul, circulavam panfletos conscientizando os dançarinos sobre a discriminação no Brasil e convidavam os festeiros para se juntar ao movimento negro. ${ }^{95}$ Suas esperanças de que o soul fornecesse a "centelha" para a eventual mobilização política dos brasileiros negros era, assim, o espelho invertido dos medos iniciais da direita. Gilberto Gil, que também estava sob ataque da mídia por sua abertura à música diaspórica "não brasileira", como o reggae, explicou sua percepção da promessa que os dançarinos de soul eram para a mudança social: "Num repente, eles irão se conscientizar do seu papel no mundo e passarão a buscar novos caminhos, melhores condições de vida para si e para os outros. A música é assim. Ela toma o cara por inteiro, de surpresa." ${ }^{96}$ E Lélia Gonzalez, que em sua entrevista a Tarlis Batista tinha repudiado o soul como uma imposição externa, mais tarde lembrou os bailes como um passo importante em sua própria transição de militância esquerdista tradicional para a militância racial. $^{97}$

Como Medeiros, os defensores do soul frequentemente o retratavam como uma poderosa alternativa política ao samba. Para alguns, a oposição soul/ samba era parte de uma crítica crescente à

94 Black Rio. Um e Meio, 20 e 21 de novembro de 1977.

95 Ver Boletim do IPCN, julho de 1976.

96 BATISTA. Os Blacks no embalo do soul. Gil e Caetano Veloso expressaram abertamente apoio ao soul, que em suas visões compartilhava os objetivos de seu próprio movimento musical, a Tropicália: para desafiar o que Christopher Dunn chama de "formas de cultura nacional sancionadas pelo Estado". A Tropicália, do mesmo modo, esteve sob ataque da esquerda e da direita por suas referências estrangeiras. DUNN. Brutality Garden, pp. 178 - 80 .

97 GONZALEZ. O Movimento Negro na última década, pp. 31 - 33; PEREIRA, Carlos Alberto M. e HOLLANDA, Heloísa Buarque de (orgs.). Patrulhas ideológicas, marca reg.: arte e engajamento em debate. São Paulo: Brasiliense, 1980, pp. $202-12$. 
comercialização do samba e do carnaval, pela ditadura, como atrações turísticas: ${ }^{98}$

\begin{abstract}
"Por que esses caras não vão dançar samba?" perguntariam ainda os idiotas da objetividade. Porque a força contestatória do samba já foi completamente anulada pelas suas próprias instituições. Há muito tempo que as escolas de samba já perderam o rebolado. Ao se transformarem em empresas promotoras de espetáculos para inglês ver, aceitando, inclusive, um vergonhoso contrato de prestação de serviços com a Riotur, o que restava em termos de "expressão autêntica do povo" foi pra cucuia. $^{99}$
\end{abstract}

Essa valorização do soul sobre o samba também refletia uma mudança geracional no gosto musical entre os cariocas afrodescendentes, como no salão de baile do Clube Renascença, onde rodas de samba dos membros mais velhos disputavam espaço com o público mais jovem das Noites do Shaft. ${ }^{100}$ Mas, acima de tudo, a crítica ao samba era parte de uma política mais ampla de denúncia de como as formas "autênticas" da cultura nacional no Brasil, bem como a suposta posição dos afrodescendentes na nação, mascaravam um racismo mais insidioso do que o dos Estados Unidos ou até mesmo o da África do Sul. O antropólogo inglês Peter Fry, estudante de pósgraduação vivendo no Brasil durante a ditadura, desenvolveu uma versão clássica desta análise comparativa das relações raciais, ao traçar a sina da culinária de origem africana no período pósescravidão no Brasil e nos Estado Unidos. Graças à violenta história de discriminação racial nos Estados Unidos, argumentava ele, a soul food permaneceu, em grande medida, patrimônio culinário dos afroamericanos. No Brasil do pós-Abolição, a ausência de discriminação

98 Ver Candeia, agora no Orum, Jornegro, novembro de 1978; “ o povo não viu o carnaval! (o samba não é para quem o faz). Jornegro, março de 1978.

99 REIS, Aloysio. A Libertação é um grito SOUL. Última Hora, 27 de maio de 1976, citado no Boletim do IPCN, julho de 1976.

100 GIACOMINI. A alma da festa, pp. $207-42$. 
legal e a celebração freyreana da miscigenação cultural promoveram a feijoada ao status de prato nacional. Apesar da aparência de inclusão, "a conversão de símbolos étnicos em símbolos nacionais não apenas oculta uma situação de dominação racial [no Brasil], mas torna muito mais difícil a tarefa de denunciá-la [do que nos Estados Unidos]". ${ }^{101}$

É importante, no entanto, situar essa perspectiva nas políticas raciais características do final dos anos 70 , em vez de tomá-la como um exemplo de brasileiros despertando para a realidade de que o samba ou a feijoada criavam falsa consciência e que o soul fosse uma alternativa revolucionária. ${ }^{102}$ Não há dúvida de que o fenômeno soul revela como os intelectuais nacionalistas utilizaram o samba e as ideias de harmonia racial tanto para a construção do soul como uma ameaça, quanto para, eventualmente, depreciá-lo como alienado. Também é claro que alguns protagonistas do mercado soul e alguns dos movimentos negros usaram referenciais do soul dos Estados Unidos como uma forma de denunciar a desarmonia da presumida harmonia racial do Brasil. Mas se os críticos estavam errados ao negligenciar as maneiras com que o termo black repercutia melhor os arranjos sociais locais (como a segregação espacial) do que as ideias nacionais de mestiçagem, não devemos tampouco admitir que os referenciais raciais do soul dos Estados Unidos pudessem explicar completamente, substituir ou corrigir triunfantemente a complexa dinâmica do racismo no Brasil. Como Bryan McCann demonstrou, alguns participantes do soul abraçaram o estilo mesmo que defendessem a relativa ausência de racismo no Brasil. ${ }^{103}$ Talvez Dom Filó tenha sido quem melhor captou muitas das atitudes dos dançarinos de soul em relação aos afro-americanos que eles tão abertamente admiravam: "Sentimos que somos irmãos deles, mas como brasileiros. As condições aqui são diferentes das de lá". ${ }^{104}$

De fato, apesar do entusiasmo de muitos ativistas negros contemporâneos em relação ao soul, alguns expressaram a convicção

101 FRY. Feijoada e 'soul food', p. 53. Ver também HANCHARD. Orpheus and Power, p. 82.

102 Peter Fry oferece uma perspectiva histórica de sua interpretação inicial do soul em Feijoada e soul food 25 anos depois. In: A persistencia da raça: ensaios antropológicos sobre o Brasil e a África austral. Rio de Janeiro: Civilização Brasileira, 2005, pp. 147 - 66.

103 MCCANN. Black Pau, pp. 85 - 86.

104 Black Rio. Veja, 24 de novembro de 1976. 
de que, para ter suas reivindicações compreendidas e levadas a sério, os brasileiros negros precisaram desenvolver uma política cultural local em vez de usar uma linguagem importada. $\mathrm{O}$ mais eloquente deles foi um autodenominado "Afro-Reporter", que escreveu sob o pseudônimo de Jamu Minka. Em uma carta ao editor do boletim informativo do IPCN, ele mandou um "recado para a turma do soul":

Pelo que tenho lido, vocês só curtem o pessoal afroamericano, será? [...] Por que prestigiar apenas o pessoal lá de cima? Se eles estão numa melhor, comparando com o que temos por aqui, podem crer que isso não aconteceu por acaso. Tudo o que conseguiram foi através de muita batalha e sempre na base do apoio mútuo. Qualé, só ficar consumindo o que estão fazendo por lá não vai dar condições pra gente chegar onde precisamos chegar. [...] Só fazendo-a, prestigiando-a [arte afro que se faz no patropi] é que nós podemos ter uma arte que seja um reflexo vibrante e atualizado da experiência afrobrasileira. $^{105}$

Para Jamu Minka, a forma ideal de música afro-brasileira era a composta por Jorge Ben, que atualizou o samba com outros ritmos africanos e da diáspora (incluindo soul e funk) e em cujas letras procurou celebrar heróis negros nacionais, como Pelé ou Zumbi dos Palmares. Adotar posturas culturais dos Estados Unidos como base para uma luta de libertação racial brasileira significava ficar totalmente fora da conversa local sobre raça. Para realmente colocar uma ameaça às ideologias raciais brasileiras, argumentou ele, os ativistas devem atacá-las em sua própria base, desafiando as ideias folclóricas sobre a África, que são o fulcro das noções de mestiçagem, e redefinindo o continente africano como um modelo para a ação política e racial moderna. ${ }^{106}$ De fato, apesar das opiniões

105 MINKA, Jamu. Recado para a turma do soul. Boletim IPCN, julho de 1977.

106 Jamu Minka era colaborador da revista socialista Versus (São Paulo), cuja coluna "Afro-Latino-América" cobria regularmente a evolução do emergente movimento negro do Brasil e as lutas pela descolonização em Africa. 
contemporâneas e posteriores de que a política voltada para a África seria retrógrada e ineficaz, o ativismo construído em torno da redefinição da África na vida pública brasileira (a base de grupos como SINBA e IPCN) foi uma das preocupações dominantes dos funcionários da Polícia secreta que espionaram organizações negras no final de setenta. ${ }^{107}$ Embora a Polícia tivesse, em última instância, descartado o soul, manteve intenso interesse nas campanhas de solidariedade dos ativistas com os movimentos anti-apartheid ou marxistas pró-independência da África no início dos anos $1980 .^{108}$ Sem fazer da atenção da Polícia secreta o teste decisivo para a eficácia política de diferentes formas de ativismo, essa discrepância sugere que, no clima político sufocante da ditadura, Jamu Minka tenha marcado um ponto.

Os debates sobre o Black Rio no Brasil de meados dos anos 70 revelam os espaços estreitos e rígidos de "autenticidade nacional" em que os afrodescendentes e suas manifestações culturais foram confinados durante a ditadura. Em parte, a incapacidade de observadores de todo o espectro político para "ler" o soul como um fenômeno político, mesmo que inicialmente percebido como uma ameaça, lança uma luz sobre a conjuntura específica da distensão e suas definições de mudança da política. Confrontadas com uma vigorosa e independente cena comercial e cultural gerida por jovens negros que reivindicavam identidades modernas, moduladas internacionalmente, bem como com um novo movimento político muito menor com base em identidades raciais, tanto a direita quanto a esquerda expressavam visões totalizantes e, por vezes, sobrepostas da cultura nacional que tentavam manter as expressões culturais negras dentro das fronteiras das representações folclóricas estabelecidas. Neste sentido, a rejeição ao conteúdo político do soul, tanto pela esquerda quanto pela direita, não deve ser interpretada como um diagnóstico de sua natureza, mas como um sintoma da luta para definir espaços legítimos de contestação política no período final da ditadura. Os participantes dos bailes e do emergente movimento

107 Para uma crítica à política negra voltada à África por ativistas no início de $1980 \mathrm{e}$ pelo próprio autor, ver HANCHARD. Orpheus and Power.

108 Para mais sobre política desses grupos voltada à África (e vigilância da Polícia secreta sobre eles), ver ALBERTO. Terms of Inclusion, capítulo 6. 
negro enfatizaram esse ponto, fazendo da defesa do soul um gesto explicitamente político.

Mais importante, no entanto, o fenômeno Black Rio é uma oportunidade para repensar uma longa história de comparações entre Brasil e Estados Unidos por meio das variadas perspectivas dos próprios protagonistas brasileiros. Ele nos permite considerar como esses atores usaram a comparação (ou contrastes) como uma ferramenta política para uma variedade de propósitos, e adverte-nos contra igualar expressões de semelhança com a própria semelhança. Nas críticas dos dançarinos e dos ativistas soul à situação racial do Brasil, black representou um termo útil tomado emprestado do contexto norte-americano. Mas seu uso não traduzido - o fato de que as pessoas entendiam sua diferença com a palavra 'negro' e mantinham os dois termos separados - mostra que black não poderia explicar tudo sobre o contexto brasileiro. Em vez disso, black e negro coexistiram nas tentativas feitas pelos afrodescendentes politicamente ativos para analisar, comunicar e contestar os contornos particulares de raça e identidade nacional no Brasil da década de setenta, assim como a consciência das semelhanças do Brasil com os Estados Unidos em termos de dinâmica racial coexistiu com uma clara percepção de suas diferenças. Em seu criativo uso do black para redefinir as discussões nacionais sobre raça, brasileiros negros demonstram não terem sido "ludibriados" nem pelos padrões americanos de consciência racial, nem pelas ideias hegemônicas brasileiras de desracialização e harmonia. Da mesma forma, apesar das poderosas conotações internacionais do black, foi o contexto local da década de setenta no Brasil que deu forma às possibilidades e limitações de seus significados políticos.

RECEBIDO EM: 02/01/2016 APROVADO EM: 19/04/2016 